NBER WORKING PAPER SERIES

\title{
STEREOTYPES IN FINANCIAL LITERACY: EVIDENCE FROM PISA
}

\author{
Laura Bottazzi \\ Annamaria Lusardi \\ Working Paper 28065 \\ http://www.nber.org/papers/w28065 \\ NATIONAL BUREAU OF ECONOMIC RESEARCH \\ 1050 Massachusetts Avenue \\ Cambridge, MA 02138 \\ November 2020
}

We thank Reneè Adams, Claudia Girardone, Paola Giuliano, Andrea Presbitero as well as seminar participants to the EFiC 2019 Conference in Banking and Corporate Finance, University of Essex, and 2016 American Economic Association Meeting in San Francisco, CA, for suggestions and comments. We also thank Gaia Dossi, Nicola Villani and Doina Postica for excellent research assistance. We gratefully acknowledge financial support from the European Investment Bank Institute through its EIBURS initiative. The findings, interpretations and conclusions presented in this article are entirely those of the authors and should not be attributed in any manner to the European Investment Bank, its Institute or the National Bureau of Economic Research. All errors are our own.

NBER working papers are circulated for discussion and comment purposes. They have not been peer-reviewed or been subject to the review by the NBER Board of Directors that accompanies official NBER publications.

(C) 2020 by Laura Bottazzi and Annamaria Lusardi. All rights reserved. Short sections of text, not to exceed two paragraphs, may be quoted without explicit permission provided that full credit, including $\odot$ notice, is given to the source. 
Stereotypes in Financial Literacy: Evidence from PISA

Laura Bottazzi and Annamaria Lusardi

NBER Working Paper No. 28065

November 2020

JEL No. G53

\begin{abstract}
$\underline{\text { ABSTRACT }}$
We examine gender differences in financial literacy among high school students in Italy using data from the 2012 Programme for International Student Assessment (PISA). Gender differences in financial literacy are large among the young in Italy. They are present in all regions and are particularly severe in the South and the Islands. Combining the rich PISA data with a variety of other indicators, we provide a thorough analysis of the potential determinants of the gender gap in financial literacy. We find that parental background, in particular the role of mothers, matters for the financial knowledge of girls. Moreover, we show that the social and cultural environment in which girls and boys live plays a crucial role in explaining gender differences. We also show that history matters: Medieval commercial hubs and the nuclear family structure created conditions favorable to the transformation of the role of women in society, and shaped gender differences in financial literacy as well.
\end{abstract}

\author{
Laura Bottazzi \\ Department of Economics \\ Bologna University \\ Strada Maggiore 45 \\ 40126 BOLOGNA \\ Italy \\ and IGIER-Università Bocconi \\ 1.bottazzi@unibo.it \\ Annamaria Lusardi \\ The George Washington University \\ School of Business \\ 2201 G Street, NW \\ Duques Hall, Suite 450E \\ Washington, DC 20052 \\ and NBER \\ alusardi@gwu.edu
}




\section{Introduction}

For individuals to participate in today's economy they must be financially literate. Governments and employers have increasingly transferred the responsibility for saving and investing onto individuals. For example, the reduction of state-supported pensions in some countries means that individuals must save in order to provide for their own financial security on retirement. Consumer credit has become widely available, making it possible for people to borrow at unprecedented levels. The 2008 financial crisis demonstrated that ill-informed financial decisions-often caused by a lack of financial literacy-can have tremendous negative consequences (OECD, 2009).

Financial literacy is particularly important for the young, as they face financial decisions that have important life-long consequences. One such decision is the investment in education, i.e., whether or not to go to college and how to pay for it.

Previous research has documented very low levels of financial literacy in the population (Lusardi and Mitchell, 2014). Not only is financial illiteracy widespread, but it is particularly severe among women (Klapper and Lusardi, 2020). In an analysis of financial literacy in twelve countries, Lusardi and Mitchell (2014) show that there are strikingly similar patterns by gender. More recently, data on financial literacy in more than 140 countries show that gender differences are present everywhere, from developing to advanced economies (Klapper and Lusardi, 2020).

Most of the empirical studies use surveys that include three to five questions to measure financial literacy. Moreover, the methodology is very similar across the most popular studies; the questions to measure financial literacy are normally multiple-choice questions, with the option for respondents to say they do not know the answer, an option that women tend to choose disproportionately more than men. In this study, we deviate from previous work by focusing on data from the OECD's Programme for International Student Assessment (PISA), which provides one of the most comprehensive measures of financial literacy available, derived from as many as forty questions. Moreover, the methodology was designed to take into consideration the well-documented gender differences in answering survey questions, in particular when related to complex topics ${ }^{1}$. Importantly, we study financial literacy among 15 -year-olds, thus looking at the roots of financial literacy and examining the determinants of financial literacy when knowledge starts to be shaped and financial decisions become consequential. Our analysis is based on data from Italy because as many as 1,158 schools participated and completed the financial literacy assessment, resulting in a large sample of more than 7,000 students. Moreover, Italian girls

\footnotetext{
${ }^{1}$ One of the authors of the paper participated in the design of the PISA financial literacy questions.
} 
scored lower than boys on the financial literacy assessment and it is important to explain the gender differences in financial literacy at this initial stage of life, as gender differences are also present and large at later stages of the life cycle both in Italy and in other countries. Because financial literacy is the result of choice, we use a model that recognizes how knowledge may be shaped. As argued in several papers, beginning in adolescence, girls and boys face increased pressures to conform to stereotypical gender roles that can shape how young people become financially literate. Stereotypes can be rooted in history. To test the predictions of the model, we make use of the unique data available in PISA, for example about parental background and socioeconomic status, and we merge that data with additional information that can help explain the large variation we see in financial knowledge among the young.

We find that parental background, in particular the role of mothers, matters for the financial knowledge of girls. Moreover, we show that the social and cultural environment in which girls and boys live plays a crucial role in explaining gender differences. We also show that history matters: Medieval commercial hubs and the nuclear family structure created conditions favorable to the transformation of the role of women in society, and shaped gender differences in financial literacy.

We contribute to the literature in several ways. First, we use an as-yet unexploited set of data and we complement it with a very rich set of information, which includes historical data on commercial routes, data on the banking system, and indeces of entrepreneurial activities across the country, providing a unique set of data to study an important topic. Second, we are able to provide some compelling explanations for the gender gap in financial literacy, not explored in such detail in the existing literature. Third, we provide findings that can inform policy and programs. Because we show financial literacy has deep roots in history, culture, and the role of women in society, strong interventions are required to close such a gap; small incremental changes are unlikely to be effective.

Our paper is organized as follows: In Section 2, we provide a literature review. In Section 3, we describe the PISA survey and the level of financial literacy in Italy and we present a simple empirical model that guides our analysis. In Section 4, we discuss the empirical approach and our findings. In Section 5, we disentangle financial literacy from mathematical literacy and discuss our findings. Section 6 contains some robustness checks and discussion on causality. Section 7 focuses on the effect of financial literacy on students' savings and Section 8 concludes. 


\section{Literature review}

Bucher-Koenen, Lusardi, Alessie, and van Rooij (2014) examine several of the reasons for differences in financial literacy levels between women and men and conclude that there is no single explanation that can satisfactorily address these differences. They also note that gender differences are present among both old and young respondents. Other studies on gender gaps in financial literacy, reviewed in Lusardi and Mitchell (2014) and the references therein, show that there are not yet definitive explanations for that phenomenon. One potential reason for these differences, which has not received enough attention, is related to the measurement of financial literacy. For example, there is evidence that women and girls are more likely to skip questions in multiple choice settings (Baldiga 2014, Riener and Wagner 2017). Such behavior can be related to a desire to avoid competitive settings (Niederle and Vesterlund 2007 and 2010), and confidence and willingness to engage in tasks that are ouside of a gender-specific domain (Coffman 2014). These arguments can be relevant for the measurement of financial literacy because finance is considered primarily a male field (see Boggio et al. 2014). Thus, if women feel uncomfortable with survey questions on financial literacy, they may answer those questions differently than men, stating for example they do not know the answer, even when they have some knowledge.

Driva, Luhrman, and Winter (2016) find that boys who perform better than girls on financial literacy assessments do think that the returns on financial knowledge are higher for males and that males are more likely to deal with financial matters at work, showing that gender differences in financial literacy can also be due to an individual's expectations and interaction with others. Furthermore, Chen and Volpe (2002) find that female college students are less confident in and enthusiastic about financial topics.

Girls are also less confident about their math abilities, even if there is no difference in test performance (Weinhardt 2017). Since many of the financial literacy assessment questions involve math, this could also contribute to the measured gender gap in financial literacy. Guiso et al. (2008) document a gender gap in math among 15-year-olds in the PISA test scores. The results vary widely by country and there is a high correlation of the gender gap in math with several gender equality measures at the country level. Specifically, the gender gap in math disappears in a society with a greater gender equality. Dossi et al.(2019) show that socialization at home can explain a non-trivial part of the observed gender disparities in mathematics performance and document that maternal gender attitudes correlate with those of their children, supporting the hypothesis that preferences transmitted through the family impact childrens' behavior. 
An important work that provides useful insights is the survey by Giuliano (2017) on the role that history plays in influencing contemporary gender norms and gender differences. She argues that gender roles emerge as a response to specific historic circumstances and are highly persistent, even after the circumstances have changed. There are also strong transmission channels from parents to children. Thus, if women were not historically responsible for financial decision making and children witnessed that behavior in their parents, the historic pattern of behavior might persist, even amidst changed circumstances. Filipiak and Walle (2015) compare individuals who live in matrilineal versus patriarchal environments in India and find no gender differences in the matrilineal environment. They show that a sizable portion of the difference in financial literacy between women living in matrilineal and patriarchal societies remains unexplained and suggest nurture as a potential reason for those differences.

It is important to study gender differences, because financial literacy matters for financial behavior; those who are less financially literate save less and accumulate lower amounts of wealth, are less likely to invest in the stock market and be savvy in their investment decisions and are more likely to mismanage debt (see Lusardi and Mitchell, 2014 for a review). Women on average are found to own less wealth (e.g., Lusardi and Mitchell 2008, Neelakantan and Chang 2010), to be less likely to own stocks and more likely to invest in fixed-income securities (see Almenberg and Dreber 2015; Bajtelsmit and VanDerhei 1997). Additionally, there are gender differences not only with respect to long-term saving and investment behavior, but also with respect to short-term objectives and behavior. For example, women are found to be more financially fragile, i.e., less confident about their capacity to handle an unexpected expense (see Hasler and Lusardi (2019)). Gender differences are also found in access to and usage of financial service. Alesina et al. (2013) examine credit conditions of self-employed and small business owners in Italy and show that female borrowers systematically get worse credit conditions, even after controlling for risk characteristics and bank fixed effects. Bucher-Koenen et al. (2019) show that financial advisors systematically sell more expensive financial products to women. Female bank clients are more frequently offered expensive bank-owned mutual funds, and are less likely to get rebates on the front loads. Thus, it is important to explain not only whether gender differences exist, but also whether they are linked to behavior and whether this link is already present when people start making financial decisions. 


\section{Methodological Approach}

\subsection{Data}

To understand the determinants of financial literacy in Italy and explain the gender differences that exist among 15-year-old students, we use data from a variety of sources. The main data are taken from the PISA 2012 financial literacy assessment, which was the first large-scale international survey to measure the financial literacy levels of 15-year-old students enrolled in the compulsory education system. In addition to student performance data, PISA collects information about student and school backgrounds through questionnaires that are completed by students, heads of school, and, in some countries, like in Italy, parents.

Since its first wave in 2000, PISA has tested 15-year-old students' skills and knowledge in three key domains: mathematics, reading, and science.

In 2012, PISA introduced an optional financial literacy assessment, which became the first large-scale international initiative to assess youths' financial literacy. A sample of students were selected at random from the schools that completed PISA's core assessments to participate in the the financial literacy assessment ${ }^{2}$. The relative difficulty of each test question was assessed using scores based on the proportion of students answering it correctly. To help users interpret what students' scores mean in substantive terms, PISA scores are divided into five proficiency levels: Students in Level 1 are considered not financially literate; Level 2 is the international baseline proficiency level. Level 5 indicates high proficiency. Students at each level are expected to be proficient at the preceding level.

In Italy, 7,068 students in 1,158 schools completed the financial literacy assessment. The PISA sample from Italy is much larger than the samples from other countries and that makes the study particularly relevant.

One striking feature of the PISA data is that Italy is the only country where, on average, male Italian students score higher in financial literacy than female students. However, as shown in Figure 1, boys tend to perform better than girls in financial literacy in other countries, when accounting for students' competencies in other subjects. After accounting for students' performance in mathematics and reading, for example, boys perform better than girls in Australia, the Flemish Community of Belgium, Croatia, Estonia, Italy, Latvia, Poland, Shanghai-China,

\footnotetext{
${ }^{2}$ In general 8 students were chosen at random from each school. As many as forty questions are used to measure financial literacy and questions are designed to minimize gender differences in performance resulting from the format of the questions (see the discussion in Lusardi (2005)).
} 
Slovenia, the Slovak Republic and the United States. This means that among boys and girls of similar ability in mathematics and reading, boys perform better in financial literacy than girls. As much of the financial literacy assessment involve math, we check, in Section 5, whether our results and analyses is robust when we control for students' math literacy score.

Girls and boys are not equally represented among high- and low-performing students. Figure 2 shows that only $5.14 \%$ of boys and $1.5 \%$ of girls perform at Level 5 , while $13.94 \%$ of boys and $15.57 \%$ of girls does not reach the baseline level of financial literacy proficiency (Level 2). At Level 1 the performance in financial literacy of girls is higher than that of boys, although the difference is small and not statistically significant. On the contrary, this difference becomes negative at Level 5 and Level 4, though the group of students who reach that level is small. These facts are common to some of the OECD countries and economies participating in PISA ${ }^{3}$.

A second striking feature of the PISA data is the large regional difference in financial literacy in Italy: the difference between the best-performing region (Alto Adige) and the worst performing one (Calabria) is 92 score points, about as large as one proficiency level. Interestingly, lowest-performing regions also have the largest performance difference between boys and girls $^{4}$. Figure 3 shows that gender differences in financial literacy are not necessarily concentrated in regions with the lower income per capita, but they are also present in top-performing regions; in other words, boys are more likely than girls to perform well on financial literacy in many regions in Italy, although, when we examined financial literacy scores aggregated by four macroeconomic areas (Northeast, Northwest, Center, and South and Islands), the largest difference in performance between boys and girls is found in Italy's South and Islands area. In this macro region, the average score of boys and girls is similar to that of Colombia, the country that finished last in the financial literacy assessment. Thus, gender differences tend to be largest where financial literacy is lowest.

We try to explain this pattern of financial literacy by combining PISA data with data from other sources, creating a unique and rich set of information on the financial literacy of young people in Italy that is guided by a simple model which is reported below. We have gathered information on variables that might affect students' accumulation of knowledge at the regional

\footnotetext{
${ }^{3}$ See OECD (2014a)

${ }^{4}$ This result is not inconsistent with Figure 2 that shows that gender difference in financial literacy is higher at the highest proficiency level. For example, take Calabria, which is one of the worst performing region in terms of financial literacy scores. In Calabria, no students reach Level 4 or 5 proficiency and girls perform less well than boys at all proficiency levels. In Valle d'Aosta, few students are at Level 1 and the distribution is concentrated at Level 3, where there is not a statistically significant difference in the performance of boys versus girls.
} 
level as well as data on opinions and attitudes toward gender roles from both the Italian National Institute of Statistics (ISTAT) and the Survey on Discriminations by Gender, Sexual Orientation and Ethnic Origin. We also used data from the Bank of Italy, in particular the Survey of Household Income and Wealth (SHIW), and the Gender Equality Index developed by Amici and Stefani (2013). We gathered information from the Excelsior Survey, developed by the Excelsior Information System, which is one of Italy's main sources of information on labor market forecasts. Moreover, we used the historic data constructed by Bertocchi and Bozzano (2015a) on provinces whose main cities were on medieval commercial routes or hosted a fair or a bank in the thirteenth and fourteenth centuries. We also used the data by Bertocchi and Bozzano (2015b) and Duranton, Rodriguez-Pose and Sandall (2007) on provinces where the nuclear family was the prevailing family type in the Middle Ages. We describe below how we have used this information to construct the variables that we use in our empirical work.

What can explain these pervasive gender differences ${ }^{5}$ ? We examine this question with the empirical model reported in the next section that can serve as guidance for our empirical work.

\subsection{An empirical model of gender differences}

To explain differences in financial literacy, we have to consider models that contemplate multiples sources of influence, including from the economic and social environment. We also have to recognize that financial literacy is not exogenous but that it responds to stimuli and incentives, starting early in life. As noted in Lusardi (2015), even the rich set of information provided in the PISA data is not enough to explain the large differences one observes among 15-year-olds. One needs to dig deeper than what is normally done in the traditional models of financial literacy, that typically consider socioeconomic background.

An extensive literature focuses on the importance and persistence of cultural norms for economic decisions (Alesina and Giuliano 2010, 2014; Bisin and Verdier 2011). For example, gender norms can explain some of the differences in women's labor market outcomes over time and across countries (see Fortin 2005, 2015, and the surveys by Bertrand 2010; Fernandez 2011). The gender intensification hypothesis (Hill and Lynch 1983) contends that, beginning in adolescence, girls and boys face increased pressures to conform to stereotypical gender roles, which

\footnotetext{
${ }^{5}$ The financial literacy gender gaps might not appear as large. However, as shown by Lusardi and Mitchell (2014), relatively small financial literacy gaps affect individual choices significantly. Moreover, as discussed by Adam and Kirchmaier (2016) in the case of math, gaps may be symptomatic of bigger gender gaps that manifest themselves over time as documented by Fryer, Jr. and Levitt (2010).
} 
in turn causes them to develop increasingly differentiated gender-role identities, attitudes, and behaviors. Hence, during adolescence girls and boys are pushed to adopt culturally sanctioned gender-role identities. These pressures are thought to come from a variety of sources and are intended to prepare adolescents for their adult roles as women and men. More specificall, social psychology has emphasized the role of the same-sex parent and of the teachers in shaping gender-role identity during adolescence (Carlana 2019, Olivetti et al.2020). Our data allows us to understand whether financial knowledge is correlated with the parents and teachers attitudes as well with the environment in which girls and boys live.

Equation (1) shows our empirical model ${ }^{6}$ :

$$
f_{i, r}^{j}=\sum_{k=1}^{K} b_{i, k} x_{i, k}+d_{0}^{j} x_{i, r}^{S}+\sum_{p=m}^{f} d_{2, p}^{j} f_{i, r}^{p}+d_{3}^{j} c e_{i, r}
$$

where i denotes an adolescent who is a student and belongs to a network $\mathrm{r}$ (regions), whose gender $\mathrm{j}=\mathrm{g}$ for girls and $\mathrm{j}=\mathrm{b}$ for boys. The level of financial literacy, $\mathrm{f}_{i, r}^{j}$ is a function of multiple variables as follows: 1 . the student's observable characteristics $x_{i, k} ; 2$. the family background $f_{i, r}^{p}$ that includes the financial literacy of the parents; 3.her/his skills, $\mathrm{x}_{i, r}^{S}$, acquired at school that foster the acquisition of financial literacy 4.the cultural environment where the student lives, denoted by $c e_{i, r}$.

Also, note from Equation (1) that we expect that the role of same-sex parent in shaping the financial literacy of girls and boys is different, that is we expect $d_{2, p}^{j}$ to be different between boys and girls.

In measuring $\mathrm{f}_{i, r}^{j}$ we focus on levels of educational achievement as reflected by the PISA financial literacy score. Specific measures for each of the adolescents' characteristics come from information provided by the PISA survey combined with data from other sources, as will be explained in more detail in the next section.

Family background influences educational achievement by providing a basic set of attitudes, behavior patterns, and relevant educational inputs, all of which are usually highly correlated with a family's socioeconomic status.

Type and quality of schools can be relevant as well when it comes to explaining dif-ferences in financial literacy. A strand of the literature has focused on the relationship between school qual-

\footnotetext{
${ }^{6}$ Equation (1) can be derived from a more formal model of choice by girls and boys relying on a preference specification that is standard in economic models of conformity (see, among others, Akerlof 1980; Bernheim, 1994; Kandel and Lazear, 1992; Fershtman and Weiss, 1998; Patacchini and Zenou, 2016).
} 
ity and students'achievement. School quality has typically been proxied by several observable indicators such as teacher-pupil ratios, teacher education, teacher experience, teacher salary, or expenditure per pupil. Overall, the link between school re- sources and test scores appears to be relatively weak (Hanushek, 1997; Hanushek, 2002; Krueger, 2003). The "school effectiveness" research comes to a similar conclusion: school type matters, but not as much as do non-school factors such as the home environment (Mortimore, Sammons, Stoll, Lewis, and Ecob, 1988; Stiefel, Schwartz, Rubenstein, and Zabel, 2005; Teddlie and Reynolds, 2000; West and Pennell, 2003). Levacic and Vignoles (2002) find that the impact of school resources is small and very sensitive to misspecifica- tion. Dearden, Ferri, and Meghir (2002) suggest that while the pupilteacher ratio has no significant impact, teacher quality may be relevant but is very difficult to measure. The PISA survey contains questions that can help us control for teacher's ability.

One of the main issues with estimating family and school effects is that some of the crosssectional variation may be the result of self-selection. Families may self-select into schools based on their income and residential and educational preferences. A family with talented children may decide to live near a school that is considered to be of particularly high quality. Families themselves can invest more in the education of their children, if the children are talented. Addressing these self-selection issues is hard, and this will be discussed in detail in the empirical section. One advantage of working with Italian data is that the Italian school system is less affected by some of these issues; school quality does not vary dramatically by family income level or location as it does in some countries, such as the United States. Italian families do not choose their housing depending on the quality of the schools. Moreover, public schools are not considered of lower quality than private schools and the difference between students attending the two types of schools rests mainly on the socioeconomic status of the family, something we can control for ${ }^{7}$. We will discuss these issues in more detail later.

\subsection{Variables}

To carry out the empirical work, we need information on a large set of financial literacy determinants to be able to explain some of the gender differences in financial literacy.In this section, we describe the sources of the variables used in the empirical estimation (refer to the data appendix

\footnotetext{
${ }^{7}$ Bertola and Checchi (2013) show how in Italy private school enrolment leads to worse subsequent performance in further education or in the labor market. Using Italian data they also show that private schools attract a worse pool of students and that publicly funded schools are better suited to foster progress by more talented students. Such a evidence contrasts sharply with standard views and evidence from Anglo-Saxon countries.
} 
and Tables A2, A3, and A4 for descriptive statistics).

In the previous section we have identified and categorized the factors that may affect the difference observed in the financial literacy performance of boys and girls in four groups.

The first group is made up of individual characteristics, $x_{i, k}$, that includes students' age at the time of the survey (AGE); their gender (FEMALE); whether they have ever repeated a grade (REPEAT); their immigrant status (IMMIGRANT). We also have information on the language spoken at home, and if it is not Italian (LANG_Foreign).

The second group of variables refers to the family background. $f_{i, r}^{p}$ We measure the socioeconomic status of the family (ESCS) using the index developed by PISA, which is based on indicators such as the occupational and educational status of parents and an index of home possessions that measures family wealth and the educational resources available at home, such as books, a desk, and a computer. Students are considered socioeconomically advantaged if they are among the $25 \%$ of students with the highest PISA index of social, economic, and cultural status in their region or economy.

These are the variables emphasized in the PISA report (OECD, 2014b) and are also considered some of the traditional determinants of financial literacy, in particular among young people (see also Lusardi, Mitchell, and Curto, 2010). We also constructed an alternative measure of the economic status of the family using the Bank of Italy 's Survey of Income and Wealth (SHIW) by computing the average net disposable income of each family and matching the two data sets on the basis of the job category of each parent. The PISA survey provides a rather comprehensive description of the professional status of parents and we can use that information to identify the family gender role differences in financial literacy. The variable HOUSEWIFE is equal to 1 if the mother's occupation (as reported by students) is equal to "housewife"; 0 otherwise. We define a variable indicating whether the mother has a financial career (MOTHER_Fin.), if the mother's occupation (as reported by students) is defined as a "managerial or financial career". A similar variable indicating whether the father has a financial career (FATHER_Fin), is defined if the father's occupation (as reported by student) is defined as a "managerial or financial career".

The third group of variables is related with the different characteristics of the school attended by the students. PISA classifies schools into two categories: private or public ( PRIVATE, PUBLIC ) and specifies their location as village or town (population of less than 100,000), city (population greater than 100,000 but less than one million), or large city (population of more than one million). Schools are also divided into lower secondary schools (i.e., MIDDLE 
SCHOOL) and upper secondary school. The latter include technical schools, vocational schools, and high schools (LYCEUM). We control for the proportion of girls in the school (PROP_Girls), which is an index based on the enrollment data provided by the school principal.

We use other information regarding the school where student are enrolled, such as the proportion of math teachers (TEACH_Math), which is computed by PISA by dividing the number of math teachers by the total number of teachers; the index of cognitive stimulus (COGNITIVE) in mathematics, reported by the school principal, which measures how active the teachers are in teaching math.

We also use five items measuring teacher behavior when giving instructions as computed in the main PISA 2012 survey. In particular, we consider two kinds of teacher behavior: (i) whether the teacher asks students to present their own thinking or reasoning at some length (TEACH_Think); and (ii) whether the teacher asks questions to check whether students have understood what was taught (TEACH_Quest). Response categories were "Every lesson," "Most lessons," "Some lessons," and "Never or hardly ever".

Finally, the last group of variables are related to the local environment, $c e_{i, r}$ : Since the local environment can influence positively or negatively the decision to acquire economic and financial knowledge we have gathered information on the cultural environment at the regional level. We expect that, in regions where people use media that are more sophisticated, discuss frequently about politics or are more active politically, the acquisition of financial knowledge is easier. MEDIA_Soph is a variable that measures the percentage of people watching TV, listening to radio, and reading newspapers (higher value=higher sophistication, i.e., more newspaper, more radio, less TV) in 2012. POL_Talk is the percentage of people who talk about politics every day. ACT_Pol is the percentage of people who attended a political meeting, took part in a political parade, or volunteered for a political party. We then control for other local characteristics that should incentivize the acquisition of financial literacy. ENTR is the number of "Individual entrepreneurs, owners, or members of family business working as shareholders/partners" over the total population. Calculations are based on data from the Bank of Italy's SHIW. BANKS is the number of bank branches per 1,000 inhabitants; FINANCE_Firms, the number of firms in the financial sector over the population. From the Excelsior survey, we derive the projected hiring in the financial sector (JOB_Fin) (non-seasonal jobs) over total non-seasonal projected hiring for 2012 and the projected hiring for people with an administrative/commercial qualification over total projected hiring (JOB_Adm) for 2012. On the contrary, the existence of different beliefs 
regarding the role of women in society and in the economy might increase the cost of acquiring financial knowledge. Gender differences at the regional level are captured by the Gender Equality Index developed by Amici and Stefani (2013). An alternative index is the Italian Gender Gap Index (IGGI) by Bozzano (2012), which is formulated by taking into account several measures of gender equality, such as access to economic resources, political and public power, educational attainment, and health. Of these four dimensions we use only the first two, as there is no regional heterogeneity in the educational attainment and health. We also use the Stereotype Index which is based on a survey on prejudice by gender, sexual orientation, and ethnic origin, which was carried out for the first time in 2011 thanks to an agreement between ISTAT and the Department of Equal Opportunities. We use only four questions from the survey. The survey asks whether the interviewee agrees with these statements: (1) That it is mainly the man who has to take care of the economic needs of the family, (2) that it is the man who makes the most relevant decisions in the family, (3) that it is more important for men than for women to have a university degree, and (4) that men are less suitable for household chores.

Finally, we used some historical variables that have been found to be related to the gender gap in Italy in other works. Bertocchi and Bozzano (2015a) computed the percentage of provinces in a region (COMM_Route) whose main city was on a Medieval commercial route or hosted a fair or a bank in the thirteenth and fourteenth centuries. As shown by Bertocchi et al.,(2015a) back in medieval Italy, the effect of trade on the promotion of women's education run through two parallel and mutually reinforcing channels that reflected fundamental economic incentives. Bertocchi and Bozzano (2015b) and Duranton, Rodriguez-Pose, and Sandall (2007) also constructed a variable measuring the nuclear family structure (NFS), which reports the percentage of provinces in a given region in which the nuclear family was the prevailing family type during the Middle Ages. The nuclear family structure is defined as one in which children form independent families once they reach adulthood (Todd, 1990). From Bertocchi and Bozzano (2015b), we compute the percentage of provinces per region which were in the first (1stQ) and fourth quantile (4thQ) of female primary school enrollment in 1861.

As described above, the reasons for differences in financial literacy among the young are many and result from different influences. Traditional models have not been able to explain the gender differences we observe in the data. The rich information that we have available allows us to go many steps further than other studies have done so far by both being more specific about what specific parts of the socioeconomic background matters and considering a wider set 
of potential influences.

\section{Results}

We turn now to the empirical results. We start with some basic specifications and then enrich the estimation by adding the new variables we have available in our data set.

Table 1 presents our baseline specification and results ${ }^{8}$.

In column (1), we regress the financial literacy score on the gender dummy (FEMALE), controlling for regional fixed effects, as the survey is representative at the regional level. The estimates confirm that female respondents score worse than their male schoolmates do, -12.46 points lower, on average. When we add controls for school type, student characteristics, family characteristics, and intra-regional school location, as reported in column (2), the gender dummy continues to be negative and highly statistically significant; girls score worse than boys and the gap is, on average, 19 points: roughly $4 \%$ less than males. All specifications include regional fixed effects.

As discussed earlier, we need to go beyond these characteristics to explain why girls are less financially literate than boys. Before we do so, we note that the estimates reported in Table 1 show a few important findings that also speak of the quality of the data. For example, many of the estimates have the expected sign or the sign reported in other works. Specifically, older students know more. Students who repeat a year (thus, are academically poorer) perform worse on financial literacy measures. Students from an immigrant background or who speak a different language at home do worse on financial literacy measures-a finding that appears in many other countries (OECD, 2014b) and in studies of adult populations (Lusardi and Mitchell, 2014) as well. Financial literacy knowledge varies by school type: students enrolled in technical, professional, and vocational schools perform $4 \%$ to $15 \%$ worse on financial literacy than students attending lyceums. Students in private schools (which in Italy are normally not of higher quality than public schools and are often considered remedial and attended by students who do poorly

\footnotetext{
${ }^{8}$ The whole sample for Italy is of 7.068 observations and we use 4651 observations in our regressions, that is $65 \%$ of the sample. In fact, the number of observations drops dramatically when we control for school location, parents' education and teachers' subject of expertise and behavior. Note that the information on mothers' professional life is missing for a relevant number of students and the information on fathers' job is missing either because of no response or because there is no father in the household. Ideally, we would like to control for total family size and for the characteristics of siblings. The average score in financial literacy is slightly higher in the restricted sample we use (480 instead of 466) but the distribution of observations in the five proficiency levels of girls and boys is not affected, especially at the top levels of efficiency. We lose observations for the students in the low efficiency level where the difference in financial literacy scores, among girls and boys is not statistically significant.
} 
in public schools) score $4 \%$ lower than students in public schools. Interestingly, students in schools where the proportion of girls is higher perform worse, while students in schools with higher proportions of math teachers score better. As found in all other countries participating in the PISA financial literacy assessment, higher socioeconomic status positively affects financial literacy scores, and it explains $8 \%$ of the variance of the difference in financial literacy between girls and boys in Italy. Finally, having a mother who is a housewife is negatively associated with financial literacy, even after controlling for many variables relating to the family. It implies that having a working mother increases the score of boys and girls by 19 point on average.

These initial estimates, given the richness of the data, start telling a story about the determinants of financial literacy. To understand the relevance of our model we proceed with a variance decomposition. Our model explains $36 \%$ of the variance of the difference in financial literacy between girls and boys. In particular students' characteristics explain $5.5 \%$ of the variance, and family characteristics $9 \%$. When we add school and professor characteristics we are able to explain $26 \%$ of the variance, and we go to $36 \%$ when we add controls for the environment where students live, that is, regional fixed effect and some indices of cultural gender bias.

Columns (3) to (6) report the estimates by macro regions. All the results remain roughly unchanged and the gender difference continues to be large; girls have much lower scores than boys, even in the Northeast, which is the macro area where students attain the highest PISA score. Even after accounting for many variables, the gender difference remains largest in the South and the Islands, where students perform the worst overall. Interestingly, this is the only macro area where the index of socioeconomic status is statistically significant. Thus, gender differences are present everywhere in Italy, an indication of the depth of this issue.

One might wonder whether these factors affect achievement differently at different points of the test score distribution. For example, while gender matters for average test scores, is it also relevant at the top and bottom of the distribution? In short, we not only can address the question does gender matter? but also, for whom does it matter?

To do so, we perform quantile regressions, which estimate the effect of the explanatory variables on the dependent variable at different points of its distribution ${ }^{9}$. Our regression specification follows the standard specification of column (2) of Table 1.

The quantile regression results reported in Table 2 shows that there are differences across the distribution of the financial literacy score. At the lower end of the distribution, the coefficient

\footnotetext{
${ }^{9}$ We do not use the five levels because there are too few students at the top levels, but findings are overall similar when we use that specification and combine levels 4 and 5 .
} 
for gender is negative and statistically significant. However, it is negative and much larger at the median and at the 0.75 and 0.90 quantiles. Thus, the difference in performance of boys and girls widens as we move up the score distribution. Another important result relates to the coefficient estimate on the index of socioeconomic status. In the quantile regressions, the coefficient is positive and insignificant at the lower percentiles, but it is relatively large and significant for the upper tail of the distribution, suggesting that this factor is particularly important for high levels of financial literacy.

A notable result is also the importance of math teachers, as seen in both the OLS and the quantile regressions. The value of the coefficients varies between 1.96 in the OLS regression and 2.26 in the quantile regression. The estimates in the OLS regression implies that a $10 \%$ increase in the proportion of math teachers in schools leads to $4 \%$ average gain in individual test scores; the results for the quantiles is similar except that the gain is $4.5 \%$ for the 0.90 quantile and less for lower quantiles.

Our findings so far show that girls tend to perform worse than boys do, even after controlling for student, family, and school characteristics. A possible issue is whether our results are affected by selection on observables. Using an analysis of pairs, matched on a conditional probability of being female (propensity score), we assess the effect of the baseline characteristics on the financial literacy score. A propensity score (for being female) is calculated from the baseline characteristics. The analysis is reported in the Appendix, Table A1. The results confirm the main findings of our analysis.

\subsection{Parents}

We now attempt to dig deeper and consider the effect that parents have on the acquisition of financial knowledge of children. We look at whether parents who work in the financial sector in particular if the mother or father has a career in finance - influence the acquisition of financial literacy and, if they do so, whether their influence is different depending on the sex of their kids. For example, mothers working in finance might be more likely to pass their gender roles views to their daughters. In particular, it is the mothers' human capital (rather than whether they work or not) that could drive gender norms and the financial literacy acquisition.

Table 3, column (1) reports the results of our baseline specification for comparison. Column (2), shows that girls who have a mother who works in finance are much less disadvantaged in their financial knowledge. Fathers' careers are less consequential; neither girls' nor boys' financial 
knowledge is affected by having a father with a career in finance. When we split the sample between boys and girls and re-estimate the main model, our results are strongly confirmed (column (3) and (4) in Table 3). These results indicate that the parental "role model" mainly affects girls. In particular, the gender role model of mothers increases the daughters' financial knowledge score by more than $5 \%$.

This is an important finding given the potential relevance of the role of parents, and it sheds some light on how girls acquire financial literacy.

\subsection{The local environment}

We now turn to examine in more detail how regional factors explain gender differences in financial literacy. The smallest geographical unit we can identify is the region, and the main regional characteristics we control for are explained in Section 3. We expect that in regions where political interest, active political participation, and media sophistication - the latter being an index whose value is higher when people report reading newspapers rather than watching $\mathrm{TV}$ as a mean of news acquisition - are higher, students will be more active socially and potentially more interested in financial issues and, therefore, more knowledgeable. Table 4a columns 1-3 show that our intuition was only partially correct. Interestingly, most of the effects work through gender. Political participation does not affect boys' financial literacy scores but decreases girls' scores. Media sophistication does not affect boys' performance but does positively affect girls' performance. In regions where people actively participate in political life, girls are less knowledgeable of finance, while in regions where the cultural level (as captured by media sophistication) is higher, the gender gap in financial literacy is (slightly) lower.

We further control for the presence of bank branches, financial firms, and entrepreneurs, as they might turn students' attention and interest toward financial topics and incentivize them to seek financial knowledge. We also control for the projected percentage of hiring in the financial sector and for the projected percentage of hiring of people with an administrative/commercial qualification, and we interact these measures with the female dummy, as better job perspectives on the financial sector might influence choices and interests of adolescents. In all cases, we find that a greater number of financial intermediaries and job opportunities increases financial literacy levels among all students, but more so among girls. Yet, the economic effect of these variables is small. On average, these regional characteristics increase girls' financial knowledge by only a few percentage points. 
Table 4b examines the financial literacy gender gap in an historical perspective. We control for the percentage of provinces in a region that were on a medieval commerce route. Bertocchi and Bozzano (2015a) find that medieval commercial hubs created conditions favorable to the transformation of the role of women in society, with more egalitarian cultural norms and beliefs transmitted through the generations. In the second column of the table, we focus on the influence of the family structure, following Bertocchi and Bozzano (2015b), with an indicator that measures the structure of the family. The nuclear family structure (NFS) is defined as one in which children form independent families once they reach adulthood (Todd, 1990). Bertocchi and Bozzano (2015b) find that this family structure is a major driver of the education gender gap, with a higher female to male enrollment ratio in upper primary schools associated with living in a community with a predominantly nuclear family structure.

The findings in Table $4 \mathrm{~b}$ show that history matters when it comes to financial literacy: moving from the region Campania to Piemonte, i.e., moving from the 25th to the 90th percentile of the distribution of historical percentage of provinces on commercial routes, increases the average PISA score of girls by 73 points, affecting the correspondent gender difference, but only marginally.

Interestingly when we control for the Stereotype Index, which measures incidents of discrimination by gender, the difference in financial literacy between girls and boys dis- appears. More precisely, both men and women who live in regions where people conform to cultural stereotypes have lower financial literacy. However, girls who live in regions in which the Stereotype Index is one standard deviation below the average, i.e., regions where the cultural attitude is in favor of more gender equality, have financial literacy that is 23 points higher than that of boys.

Our results support recent findings showing that stereotypes can explain gender gaps in various domains (Bordalo et al. 2015, Lavy and Sand 2015). Dossi, Figlio, Giuliano, and Sapienza (2018) show that girls growing up in a gender-biased family score, on average, 3 percentage points lower on math exams than girls raised in other types of families.

We also examine the effects of controlling for a Gender Equality Index (GEI), an indicator that considers four dimensions: work, income, political and economic representation, and use of time among women. We find evidence that in regions where the index is high, boys' financial literacy is lower, while girls' financial literacy is significantly and marginally higher. This is also what we find when we control for the Italian Gender Gap Index (IGGI) developed by Bozzano (2012), an index which focuses more on women's political participation. However the two indexes 
are highly correlated.

To summarize, many factors explain why young women grow up to learn less about finance and money matters. While explanations linked to demographic characteristics, quality of schools and teachers, and socioeconomic background are important, they are not enough to explain the financial literacy gender gap, as many other studies have also shown. Our work is unique in showing that we need to look more closely at the role of women in society, which is deeply rooted in history. Stereotypes strongly influence how young girls relate to finance. Moreover, parents are role models for children, and we find that girls learn about finance from mothers who work in financial fields. Some of these explanations are powerful enough to fully account for the gender differences seen across students and regions of Italy.

\section{The role of math literacy}

As discussed in the introduction, and in Section 3, in numerous countries the gender difference in financial literacy is affected by math literacy. As financial literacy requires some mathematics skills, we now examine whether much of the lack of financial literacy and gender difference in financial literacy is attributable to math illiteracy, which we know affects many Italian students.

In Table 5, we see students' financial knowledge at different quantiles of math literacy. The difference in financial literacy between boys and girls disappears when we compare adolescents who have high math literacy: At the 90th percentile of math literacy, there is no difference in financial literacy levels of female and male students. This result could also be due to the low number of observations in this percentile interval and to the low number of girls as well: they represent only $30 \%$ of the students in the 90th percentile of math literacy.

We then replicate the regression of Table $4 \mathrm{~b}$, adding the math literacy score index as an explanatory variable. As expected, the math literacy index plays an important role in explaining the financial knowledge of students. Interestingly, we are now able to explain $57 \%$ of the variance of the financial literacy gap, although the main results do not change; our base specification continues to show that the difference in financial literacy scores between girls and boys remains statistically significant. In particular, Table 6 shows that history continues to be a relevant explanatory factor. Regions with a high proportion of provinces that were historically on a commercial route, or characterized by greater political and economic representation of women, measured by the GEI index, or by greater access to economic resources, political and public 
power measured by the IGGI index, perform better. This finding is not completely surprising because several of the questions that comprise the financial literacy assessment are not related to math or to calculations.

The most interesting results are shown in column (2). When we control for the percentage of provinces in a given region in which the nuclear family was the prevailing family type during the Middle Ages, no differences in financial literacy between boys and girl is detected. On the contrary, boys have lower financial literacy scores in the regions where the percentage of NFS is higher. This result is in line with Duranton et al.(2007), i.e., people living in regions with an egalitarian nuclear family structure tend to have a lower level of education, with no gender difference in level of education. Column (3) shows the Stereotype Index, controlling for math literacy. This index captures the stereotype culture in Italian regions. The results are striking: in regions with very low levels of the Stereotype Index, girls perform (slightly) better than boys on the financial literacy assessment. This effect vanishes, and is even reversed, in regions with high levels of the Stereotype Index; in other words, in regions where individuals think that women do not have to work and provide financial support to the family, boys demonstrate higher financial literacy than girls.

\section{Robustness checks}

In this section, we perform a number of checks that show that our findings are robust. Specifically, we look closely at school effects, the influence of the family and the local environment.

\subsection{More on school effects}

When looking at school effects, we can distinguish between the organization of the school and the teaching method. Our base specification includes controls for the type of school (lyceum, technical, professional, or vocational) and for private or public designation. As discussed in Section 4, students enrolled in a lyceum perform much better on the financial literacy assessment. However, this result may be due to the more elite students choosing to attend a lyceum, which is perceived in Italy as one of the best types of schools. Moreover, our baseline specifications highlight the relevance to the financial literacy scores of the proportion of girls and number of math teachers at a school. We take the proportion of girls at school as a measure of the type of school attended: the classic lyceum, which is dedicated to humanistic studies such 
as latin, ancient greek, italian, history, and philosophy tends to attract more girls, while the scientific lyceum, dedicated to scientific studies and more oriented toward mathematics, physics, chemistry, biology, earth science, and computer science tends to attract more boys. As PISA does not allow us to distinguish among different types of lyceum, we classify them based on the number of math teachers over the total number of instructors in the school. We then classify as "scientific" all of the lyceums where the proportion of math teachers is higher than $17 \%$, which is the average percentage of math professors in the lyceums. To address a possible selection bias on unobservables, we perform a Heckman selection model estimation. In the first stage, we estimate the probability of a student selecting enrollment in a scientific lyceum, controlling for the variables in our base specification but including, as an identification variable, the number of scientific lyceums per inhabitant at the regional level. The hypothesis is that the supply of scientific lyceums (per capita) affects the students who go to that type of school, as Italian students do not tend to move away from their hometown when attending high school. Table 7 shows the result of the first and second stages of the Heckman estimation. Students from families with high socioeconomic status are more likely to enroll in lyceums, while students who have repeated a grade tend to enroll in professional and technical schools. Interestingly, the estimated coefficients, apart for the one of lyceum in the second stage, are not different from the one shown in column (1). In short, there is no evidence of selection.

We turn next to the examination of whether school practices affect student performance. In Table 8, we look at the effect of teaching practices. First, we look at the measure of teacher behavior when giving instructions, as provided by PISA.

Students were asked to report the frequency with which the teacher asks them to present their thinking or reasoning at some length in math lessons (TEACH_Think) or how often the teacher asks questions to check whether they understand what is being taught (TCH_Quest). The first column of Table 8 reports the baseline specification, as the questions on teaching methodology were asked only to a subsample of PISA respondents. Interestingly, as seen in columns (2) and (3), girls who report higher levels of cognitive stimulus in their math lessons perform nearly as well (the difference is of roughly $2 \%$ ) as boys on the financial literacy assessment.

We then look at the index of cognitive stimulus in math (COGNITIVE), which measures the extent to which teaching strategies encourage students to think more deeply in order to find solutions and to focus on the method used for reaching the answer rather than on the answer itself. Interestingly, girls' financial knowledge is affected positively by the index of cognitive 
stimulus.

\subsection{More on family influence}

Children can acquire knowledge about money management by discussing money matters (e.g., talking about spending, saving, banking, and investments) within the family. We construct the variable DISCUSS_Family, which is equal to 1 if the student reports dis- cussing money matters with parents/guardians "Almost every day" or "Once or twice a week" and 0 for the remaining classifications: "Once or twice a month," "Never or hardly ever".

Parents may influence the financial knowledge of their children by discussing financial topics with them. In table 9, we assess whether students' financial literacy is affected both by the discussion of issues related to money with their parents and with their friends. Information for these interactions was obtained via questions asked to a sub-sample of respondents only. Hence, when we control for these variables, the number of observations drops substantially. For that reason, Table 9 reports, in column (1), the baseline specification estimated on the same subsample. Column (2) reports the importance and influence of the family on the development of children's knowledge: discussing money-related issues within the family increases the financial literacy score by almost 16 points for both boys and girls. This finding is reinforced when we split the sample between male and female students (columns (3) and (4)).

\subsection{More on local environment}

There is a concern of reverse causality with the Stereotype Index estimates reported in Table 4b and Table $6 \mathrm{~b}$. The opinion on the role that women play in the family and in society might be affected by their financial illiteracy, which is reflected in the performance of younger women. In order to solve the causality issue we rely on the work by Alesina, Giuliano and Nunn (2013), that studies the historical origins of current differences in norms and beliefs about the appropriate role of women in society ${ }^{10}$. In their work, they test the hypothesis that traditional agricultural practices have influenced the historical gender division of labor and the evolution and persistence of gender norms. In particular they test whether, consistent with the hypotheses of Boserup (1970), the descendants of societies that traditionally practiced plough agriculture have lower rates of female participation in today's workplace and a greater prevalence of attitudes favoring gender inequality. On the basis of their work, we instrument the Stereotype Index exploiting

\footnotetext{
${ }^{10}$ We thank Paola Giuliano for having suggested us the use of these instrumental variables.
} 
one determinant of historical plough use that has been emphasized in the anthropological literature: the type of crops grown in a particular location (Pryor, 1985). Pryor (1985) has classified crops into those whose cultivation benefits greatly from the adoption of the plough, which include wheat, teff, barley and rye (plough positive crops) and those whose cultivation benefits less (plough-negative crops), which include sorghum, and millet. We use the same two instruments constructed by Alesina et al (2013). We measure geo-climatic conditions that impact the suitability of a location for growing both plough positive and plough negative crops using the information on the suitability of a location for their cultivation from the FAO's Global AgroEcological Zones (GAEZ) 2002 database (Fischer et al., 2002). The database reports suitability for the cultivation of numerous crops for 5 arc-minutes by 5 arc-minute grid-cell globally, and in our case for Italy. The data are then combined with the specific growing requirements of crops, to produce a measure of whether the crop can be grown productively in a location. The two instruments are then constructed by computing the ratio of the amount of land suitable for the production of these cereals with the total arable land, for each Italian region. ${ }^{11}$.

Table 10 reports the estimates using the constructed instrumental variables. Columns 2 and 4 report the first stage estimates which show that the historical suitability for the cultivation of plough-positive cereals is always positively correlated with the Stereotype Index, while suitability for the cultivation of plough-negative cereals is generally negatively correlated with the Stereotype Index. The F-test for joint significance of the two instruments is also reported in the table and it is strongly significant.

The IV estimates, reported in columns 1 and 3 confirm the estimates of Table 4 and Table 6 . Higher values of the Stereotype Index, instrumented, are associated with lower financial literacy both for girls and for boys, even when we control for the math ability.

\section{Savings and financial literacy}

Finally, we want to understand if financial literacy affects teenagers' behavior. We already know that adults financial literacy affect their saving behavior (Guiso et al(2008), Lusardi and Mitchell (2014)) but we have less evidence for the adolescents. Existing studies of financial education among adolescents find that these programs tend to increase savings. Bruhn et al. (2013) find long-term effects on savings one year after a two-year long financial education program

\footnotetext{
${ }^{11}$ We refer to Alesina et al. (2013) for a deep explanation of the instrumental variables construction.
} 
and Berry, Karlan and Pradhan (2015) find similar short-term effects, after a nine-month long program.

The PISA data gives us the opportunity to check whether existing financial knowledge affects adolescents saving and intertemporal choices as it records students' attitude toward money. We have constructed two variables that represent individuals' propensity to save. The first variable (PSAVE_A) is equal to 1 , if students answer "Which of these statements about saving money best applies to you?" with one of the following: "I save the same amount of money each week or month," "I save some money each week or month, but the amount varies," "I save money only when I have some to spare," or "I save money only when I want to buy something," and it is equal to 0 if the student answers "I do not save any money". The second variable (PSAVE_B) is equal to 1 if students answer "If you don't have enough money to buy something you really want (for example, an item of clothing, sports equipment . etc,.), what are you most likely to do?" with "I save up to buy it" and equal to 0 otherwise. As these questions were asked to only half of a non-overlapping sample of students taking the financial literacy survey, we had to construct two variables that are defined for half of the sample.

Table 11 looks at saving behavior. In columns (1) and (2) we use definition PSAVE_A while columns (3) and (4) consider definition PSAVE_B. The table shows that girls tend to save less, although the dummy female is statistically significant only at 10 percent and only for one definition of saving. This result might appear counter-intuitive, as women tend to adopt a more parsimonious behavior ${ }^{12}$. However, from the PISA survey, we also know that girls have less pocket money. Therefore, the negative sign can be interpreted as evidence of a liquidity constraint. Indeed, when we dig deeper into this result we find that $70 \%$ of the adolescents that answer that they have no money to spare are girls. If we discard these observations the negative coefficient on female become positive but not statistically significant. Interestingly, boys with higher financial literacy do not save more. On the contrary, when we restrict the sample only to girls the effect of financial literacy is statistically significant and economically relevant: on average financially literate girls have 18 percent higher probability to save to cope with future contingencies (PSAVE_A ${ }^{13}$. Moving from the 25 th percentile to the 75 th percentile in financial literacy increases the probability of saving by 3 percent and it increases by 5 percent

\footnotetext{
${ }^{12}$ We thank Claudia Girardone for having raised this important issue.

${ }^{13}$ To avoid issues of reverse causality due to the possible effect that savings has on financial literacy we have instrumented the financial literacy score with the math score index. We do not find any evidence of endogeneity. The estimations are available upon request
} 
the probability of saving to buy goods without incurring into debt.

We find the result extremely interesting.

\section{$8 \quad$ Conclusions}

We use new and unexploited data on the financial literacy of high school students in Italy to study the differences in the financial literacy between boys and girls. Italy is an interesting country to study, not only because Italian students score particularly low on the financial literacy assessment but also because Italy is the only country among those that participated in the 2012 PISA assessment that displays a gender difference in the average financial literacy score. Our empirical work confirms the findings of previous studies but also advances our knowledge and understanding of the determinants of the gender differences in financial literacy. First, we are able to document the impact of the family, in particular the role of the mother, on the financial knowledge of girls. Second, we are able to demonstrate that the social and cultural environment in which girls and boys live plays a crucial role in explaining gender differences. Moreover, we show that history matters: Medieval commercial hubs and the nuclear family structure created conditions favorable to the transformation of the role of women in society, and in those regions today, we see higher financial literacy among youths, and among girls as well.

In future work, we plan to use other waves of the PISA data, such as from the 2015 and 2018 assessments, to examine not only improvements over time but the persistence of gender differences. Unfortunately, the 2015 data is representative only at the macro area level (south, central, north-east, north-west) and not at the regional level, limiting a possible comparison with the 2012 survey. Looking at later waves will be particularly useful as, while financial literacy instruction in school is not mandatory, there are many more financial literacy programs and initiatives that have been organized for students and parents.

\section{Appendix}

\section{A.1. Selection issues}

Our findings on Tables 3 and 4 show that girls tend to perform worse than boys, even after controlling for student, family, and school characteristics. A possible issue is whether our results are affected by selection on observables. Using an analysis of pairs, matched on a conditional probability of being female (propensity score), we assess the effect of the baseline characteristics on the financial literacy score. A propensity score (for being female) is calculated from the 
baseline characteristics. One of the most common and easiest to implement and understand methods for selection is the k: one nearest neighbor matching (Rubin, 1973). Nearest neighbor matching estimates the average treatment on the treated (ATT), as it matches control individuals to the treated group and discards controls who are not selected as matches. In its simplest form, 1:1 nearest neighbor matching selects for each treated individual i the control individual with the smallest distance from individual $\mathrm{i}$. We use a $\mathrm{k}: 1$ matching where $\mathrm{k}=1,2,5$. We also perform a Kernel matching; for each treated subject, a weighted average of the outcome of all non-beneficiaries is derived. The weights are based on the distance of the non-beneficiaries' propensity score to that of the treated subjects, with the highest weight given to those with scores closest to the treated unit. The results of the propensity score show that the difference in financial literacy score between girls and boys ranges in the interval 21 to 27 points, roughly a score $5 \%$ to $6 \%$ lower for girls (TableA1). These results confirm the finding of our previous analysis. 


\section{References}

[1] Adams, R. B. and T. Kirchmaier 2016 Women on Boards in Finance and STEM Industries. American Economic Review: Papers \& Proceedings 2016, 106(5) 277-281

[2] Akerlof, G.A.,1980. A theory of social custom, of which unemployment may be one consequence. Quarterly Journal of Economics 94, 749-775.

[3] Alesina A., Giuliano P., 2010, The Power of the Family. Journal of Economic Growth, 15(2), 93-125.

[4] Alesina, A., Giuliano P., 2014 Family Ties, Handbook of Economic Growth, Vol. 2, 177-215.

[5] Alesina A., Giuliano P., Nunn N., 2013, On the Origins of Gender Roles: Women and the Plough, The Quarterly Journal of Economics, 128(2), 469-530.

[6] Almenberg J., Dreber A., 2015, Gender, Stock Market Participation and Financial Literacy, Economics Letters, 137, 140-142.

[7] Amici M. and Stefani M.L., 2013, A Gender Equality Index for the Italian Regions. Bank of Italy Occasional Paper No. 190

[8] Bajtelsmit VL., VanDerhei JL., 1997, Risk Aversion and Pension Investment Choices. Positioning Pensions for the Twenty-First Century, 45(2), 66.

[9] Baldiga K., 2014, Gender Differences in Willingness to Guess, Management Science 60(2), 434-448.

[10] Bernheim D . 1994 A theory of conformity, Journal of Political Economy 102 (S), 841877

[11] Bertocchi G., Bozzano M., 2015a. Women, Medieval Commerce, and the Education Gender Gap, Journal of Comparative Economics, 44, 2016, 496-521.

[12] Bertocchi G., Bozzano M., 2015b. Family Structure and the Education Gender Gap: Evidence from Italian Provinces, Special Issue on the Determinants of Gender Gaps, CESifo Economic Studies 61, 2015,

[13] Bertola G., Checchi D., 2013, Who Chooses which Private Education? Theory and International Evidence, Labour, 27(3), 249-71. 
[14] Bisin A., Verdier T., 2011, The Economics of Cultural Transmission and Socialization. In Handbook of Social Economics, Vol. 1, 339-416.

[15] Boggio, C., Fornero, E., Prast, H. M., Sanders, J. 2014, Seven Ways to Knit Your Portfolio: Is Investor Communication Neutral?, CeRP Working Paper Series, 140/14.

[16] Bordalo,P. Coffman K., Gennaioli N. and Shleifer,A. 2016. Stereotypes, The Quarterly Journal of Economics, vol 131(4), pages 1753-1794

[17] Boserup, E., 1970, Woman's Role in Economic Development, London: George Allen and Unwin Ltd.

[18] Bozzano, M., 2012. Assessing Gender Inequality among Italian Regions: The Italian Gender Gap Index. Rivista di Politica Economica, 103, 255-300.

[19] Bruhn M., de Souza Leão L., Legovini A., Marchetti R., Zia B., 2013, The Impact of High School Financial Education: Experimental Evidence from Brazil, The World Bank.

[20] Bucher-Koenen, T., Lusardi, A., Alessie, R. and van Rooij, M., 2014. How Financially Literate are Women? An Overview and New Insights. NBER Working Paper No. 20793.

[21] Bucher-Koenen T., Hackethal A., Koenen J., Laudenbach C., 2019, Do Seemingly Smarter People get Better Advice?. Available at SSRN 2572961

[22] Carlana M., 2019, Implicit Stereotypes: Evidence from Teachers' Gender Bias, The Quarterly Journal of Economics, 134(3), 1163-224.

[23] Chen H., Volpe RP., 2002, Gender Differences in Personal Financial Literacy Among College sStudents, Financial services Review, 11(3), 289-307.

[24] Coffman K., 2014, Evidence on Self-Stereotyping and the Contribution of Ideas, The Quarterly Journal of Economics, 129(4), 1625-1660.

[25] Dearden, L., Ferri, J., and Meghir, C., 2002. The Effect of School Quality on Educational Attainment and Wages. The Review of Economics and Statistics, 84(1), 1-20.

[26] Dossi, G., Figlio, D.,Giuliano P. and Sapienza P., 2017, Born in the Family: Preferences for Boys and the Gender Gap in Math, mimeo 
[27] Driva, Luhrman, and Winter,2016,Gender differences and stereotypes in financial literacy : Off to an early start, Economics Letters, Vol. 146, 09.2016, p. 143-146.

[28] Duranton G., Rodríguez-Pose A., Sandall, 2007, Family types and the persistence of regional disparities in Europe, Working Papers 2008-07, Instituto Madrileño de Estudios Avanzados (IMDEA) Ciencias Sociales

[29] Fershaim C. and Weiss Y.,1998, Social status and economic performance: A survey,European Economic Review 42 (1998) 801 -820

[30] Filipiak U., and Walle Y., 2015, The Financial Literacy Gender Gap: A Question of Nature or Nurture?, Courant Research Centre: Poverty, Equity and Growth-Discussion Papers, No. 176.

[31] Fischer, G., H. van Nelthuizen, M. Shah, and F. Nachtergaele, Global Agro-Ecological Assessment for Agriculture in the 21st Century: Methodology and Results, Rome:Food and Agriculture Organization of the United Nations, 2002.

[32] Fornero,E. and Monticone C., 2011. "Financial Literacy and Pension Plan Participation in Italy," CeRP Working Papers 111, Center for Research on Pensions and Welfare Policies, Turin (Italy)

[33] Fortin NM., 2005, Gender Role Attitudes and the Labour-Market Outcomes of Women across OECD Countries, Oxford Review of Economic Policy, 21(3), 416-38.

[34] Fortin NM., 2015, Gender Role Atitudes and Women's Labor Market Participation: Optingout, Aids, and the Persistent Appeal of Housewifery, Annals of Economics and Statistics/Annales d'Économie et de Statistique, 117/118, 379-401.

[35] Fryer, Jr., Roland G. and Steven D. Levitt (2010) An Empirical Analysis of the Gender Gap in Mathematics American Economic Journal: Applied Economics 2 (April 2010): 210-240

[36] Giuliano P., 2017, Gender: An Historical Perspective, National Bureau of Economic Research, No. w23635.

[37] Guiso L., Monte F., Sapienza P., Zingales L., 2008 Culture, Gender, and Math. Science-New York the Washington, 320(5880), 1164. 
[38] Hanushek, Eric A., 1997, Assessing the Effects of School Resources on Student Performance: An Update. Educational Evaluation and Policy Analysis 19/2, 141-164.

[39] Hanushek, Eric A., 2002, Evidence, Politics, and the Class Size Debate. In: Lawrence Mishel and Richard Rothstein (ed.), The Class Size Debate. Washington DC. Economic Policy Institute, 37-65.

[40] Hill, J.P. and Lynch, M.E., 1983, The Intensification of Gender-Related Role Expectations during Early Adolescence, Girls at puberty, Springer, Boston, MA, 201-228

[41] Kandel, E.,and Lazear, E. P. (1992). Peer Pressure and Partnership. Journal of Political Economy, 100, 801-817

[42] Karlan DS., Berry J., Pradhan MP., 2015, The Impact of Financial Education for Youth in Ghana, Yale University Economic Growth Center Discussion Paper, 1048.

[43] Klapper, L., Lusardi, A., and van Oudheusden, P., 2015. Financial Literacy Around the World. Insights from the Standard \& Poor's Ratings Services Global Financial Literacy Survey. http://media.mhfi.com/documents/2015-Finlit_paper_17_F3_SINGLES.pdf

[44] Klapper L., Lusardi A., 2020, Financial Literacy and Financial Resilience: Evidence form around the World, Financial Management, Vol. 49, 589-614.

[45] Krueger A.B., 2003. Economic Considerations and Class Size," Economic Journal, 113(485), F34-F63

[46] Lavy, V. Sand, E. ,2018. On the origins of gender gaps in human capital: Short- and longterm consequences of teachers' biases,Journal of Public Economics, vol 167, pages 263-279

[47] Levacic R.,Vignoles A., 2002. Researching the Links between School Resources and Student Outcomes in the UK: A Review of Issues and Evidence, Education Economics, 10(3), 313331.

[48] Lusardi A., Mitchell OS., 2008, Planning and Financial Literacy: How do Women Fare?, American Economic Review, 98(2), 413-17.

[49] Lusardi, Annamaria, Olivia S. Mitchell, and Vilsa Curto. 2010. Financial Literacy among the Young. Journal of Consumer Affairs, 44 (2): 358-380. 
[50] Lusardi, A., Mitchell O.S., 2014. The Economic Importance of Financial Literacy: Theory and Evidence. Journal of Economic Literature, 52(1), 5-44.

[51] Lusardi, A., 2015a. Risk Literacy." Italian Economic Journal, 1(1), 5-23.

[52] Lusardi, A. 2015b. "Financial Literacy Skills for the 21th Century: Evidence from PISA." Journal of Consumer Affairs, 49(3), 639-659.

[53] Mortimore, P., Sammons, P., Stoll, L., Lewis, D. \& Ecob, R.,1988,. School Matters, the Junior Years. Wells, Open Books.

[54] Muriel N., Vesterlund L., 2007, Do Women Shy away from Competition? Quarterly Journal of Economics, Vol. 122(3), 1067-1101.

[55] Muriel N., Vesterlund L., 2010, Explaining the Gender Gap in Math Test Scores: The Role of Competition, Journal of Economic Perspective, 24(2), 129-144.

[56] Neelakantan U., Chang Y., 2010, Gender Differences in Wealth at Retirement, American Economic Review, 100(2), 362-67.

[57] OECD, 2009, Education at Glance 2009, Paris.

[58] OECD, 2014a, Education at Glance 2014, Paris.

[59] OECD, 2014b. PISA 2012 Results: Students and Money (Volume VI): Financial Literacy Skills for the 21st Century, PISA, OECD Publishing, Paris. http://dx.doi.org/10.1787/9789264208094-en

[60] Olivetti,C, Patacchini,E and Y Zenou 2020."Mothers, peers, and gender-role identity"Journal of the European Economic Association 18 (1), 266-301

[61] Patacchini, E., and Y. Zenou 2016, \ocial networks and parental behavior in the intergenerational transmission of religion, Quantitative Economics 7(3), 969-995

[62] Pryor, Frederic, 1985, The Invention of the Plow, Comparative Studies in Society and History, 27(4), 727-743

[63] Riener G., Wagner V., 2017, Shying away from Demanding Tasks? Experimental Evidence on Gender Differences in Answering Multiple-Choice Questions, Economics of Education Review 59(C), 43-62. 
[64] Rubin D.B., 1973. Matching to remove bias in observational studies. Biometrics. 29:159-184.

[65] Stiefel, L., Schwartz, A. E., Rubenstein, R. \& Zabel, J., 2005. (Eds.) Measuring School Performance and Efficiency: Implications for Practice and Research (67-92). NY: Eye on Education, Inc

[66] Teddlie, C., and Reynolds, D., 2000. School effectiveness research and the social and behavioural sciences. In C. Teddlie, \& D. Reynolds (Eds.)

[67] Todd, E., 1990, L'invention de l'Europe, Paris: Seuil.

[68] West, A. and Pennell, H., 2003. Underachievement in schools School concerns. Routledge Falmer, London, UK. 
Table A1: Propensity Score Matching

\begin{tabular}{llcc}
\hline Financial Literacy Score & Coefficient & $\mathbf{z}$ & $\mathbf{P}>|\mathbf{z}|$ \\
\hline NNM 1:1 & $-22.08^{* * *}$ & -5.53 & 0.00 \\
NNM 2:1 & $-21.05^{* * *}$ & -5.99 & 0.00 \\
NNM 5:1 & $-21.71^{* * *}$ & -6.92 & 0.00 \\
Kernel (no weights) & $-23.02^{* *}$ & -2.63 & 0.01 \\
Kernel (weights) & $-27.13^{* * *}$ & -10.16 & 0.00 \\
\hline
\end{tabular}

NOTE: The table computes the difference in financial literacy score between girls and boys using a propensity score (for being female) matching calculated from the baseline characteristics. NNM refers to nearest neighbour matching with $\mathrm{j}$ : h population weights. Kernel (no weights) is Kernel (Epanechnikov) matching, without common support and without population weights.

${ }^{* *} \mathrm{p}<0.01,{ }^{* *} \mathrm{p}<0.05,{ }^{*} \mathrm{p}<0.1$ 


\section{Table A2: Description of the Main Variables}

\begin{tabular}{|c|c|c|c|}
\hline Variable & Name of the Variable & Source & Definition \\
\hline Age of student & AGE & OECD PISA (2012) & $\begin{array}{l}\text { The age of a student (AGE) was calculated as the dif- } \\
\text { ference between the year and month of the testing and } \\
\text { the year and month of a student's birth. Data on stu- } \\
\text { dent's age were obtained from both the questionnaire and } \\
\text { the student tracking forms. If the month of testing was } \\
\text { not known for a particular student, the median month of } \\
\text { testing for that country was used in the calculation. }\end{array}$ \\
\hline City Dummy & CITY & OECD PISA (2012) & $\begin{array}{l}\text { School is located in a city of } 100,000 \text { to about one million } \\
\text { people. }\end{array}$ \\
\hline $\begin{array}{l}\text { INDEX for Cognitive } \\
\text { activation in Math } \\
\text { lessons }\end{array}$ & COGNITIVE & OECD PISA (2012) & $\begin{array}{l}\text { Nine items measuring cognitive activation in mathemat- } \\
\text { ics lessons (COGNITIVE) were used in the Main Survey } \\
\text { of PISA 2012. The list below shows the questions start- } \\
\text { ing from which the index was built. Response categories } \\
\text { were "Always or almost always", "Often", "Sometimes" and } \\
\text { "Never or rarely". All items were reversed, so the higher } \\
\text { difficulty corresponds to the lower frequency of the event } \\
\text { in the classroom. a) The teacher asks questions that make } \\
\text { us reflect on the problem; b) The teacher gives problems } \\
\text { that require us to think for an extended time; c) The } \\
\text { teacher asks us to decide on our own procedures for solving } \\
\text { complex problems; d) The teacher presents problems for } \\
\text { which there is no immediately obvious method of solution; } \\
\text { e) The teacher presents problems in different contexts so } \\
\text { that students know whether they have understood the } \\
\text { concepts; g) The teacher asks us to explain how we have } \\
\text { solved a problem; f) The teacher helps us to learn from } \\
\text { mistakes we have made; h) The teacher presents problems } \\
\text { that require students to apply what they have learned to } \\
\text { new contexts; i) The teacher gives problems that can be } \\
\text { solved in several different ways. }\end{array}$ \\
\hline $\begin{array}{l}\% \text { of provinces which } \\
\text { were on a medieval } \\
\text { commercial route }\end{array}$ & COMM_Route & Bertocchi et al. (2015) & $\begin{array}{l}\text { Calculated as the number of provinces whose main city } \\
\text { was on medieval commercial routes or was the seat of a } \\
\text { fair or a bank in the thirteen to fourteen century over total } \\
\text { number of provinces in the region. }\end{array}$ \\
\hline $\begin{array}{l}\text { Discuss money with } \\
\text { parents every day or } \\
\text { once or twice a week }\end{array}$ & DISCUSS_Family & OECD PISA (2012), own elaboration. & $\begin{array}{l}\text { Variable equal to } 1 \text { if, when asked "How often do you } \\
\text { discuss money matters (e.g. talk about spending, sav- } \\
\text { ing, banking, investment) with parents/guardians or other } \\
\text { adult relations?", the student ticked one of the following } \\
\text { boxes: "Almost every day" or "Once or twice a week". It is } \\
\text { equal to } 0 \text { if the student ticked one of the following: "Once } \\
\text { or twice a month", "Never or hardly ever". }\end{array}$ \\
\hline $\begin{array}{l}\text { Index of economic, so- } \\
\text { cial and cultural status }\end{array}$ & ESCS & OECD PISA (2012) & $\begin{array}{l}\text { The PISA index of economic, social and cultural status } \\
\text { (ESCS) was derived from the index of highest occupa- } \\
\text { tional status of parents (HISEI), the index of highest ed- } \\
\text { ucational level of parents in years of education according } \\
\text { to ISCED (PARED), and the index of home possessions } \\
\text { (HOMEPOS). The index of home possessions (HOME- } \\
\text { POS) comprises all items on the indices of WEALTH, } \\
\text { CULT POSS and HEDRES, as well as books in the home } \\
\text { recoded into a four-level categorical variable (0-10 books, } \\
11-25 \text { or } 26-100 \text { books, } 101-200 \text { or } 201-500 \text { books, more } \\
\text { than } 500 \text { books). }\end{array}$ \\
\hline
\end{tabular}




\begin{tabular}{|c|c|c|c|}
\hline Variable & Name of the Variable & Source & Definition \\
\hline $\begin{array}{l}\text { Parent expects finan- } \\
\text { cial career (broad def- } \\
\text { inition) }\end{array}$ & EXP_Fin & OECD PISA (2012), own elaboration. & $\begin{array}{l}\text { This variable is equal to } 1 \text { if the parent/guardian who } \\
\text { completed the parents' questionnaire indicated a "man- } \\
\text { agerial or financial career" (see attached file on definition } \\
\text { of financial career) when asked: "What occupation do you } \\
\text { expect your child to have when they are about } 30 \text { years } \\
\text { old?". }\end{array}$ \\
\hline $\begin{array}{l}\text { Father has a financial } \\
\text { career (broad defini- } \\
\text { tion) }\end{array}$ & FATHER_Fin & OECD PISA (2012), own elaboration. & $\begin{array}{l}\text { This variable is equal to } 1 \text { if the father's occupation (as re- } \\
\text { ported by student) is defined as a "managerial or financial } \\
\text { career" (see attached file on definition of financial career). }\end{array}$ \\
\hline Female & FEMALE & OECD PISA (2012) & $\begin{array}{l}\text { Dummy variable equal to } 1 \text { if the student is a female and } \\
\text { equal to } 0 \text { if is a male. }\end{array}$ \\
\hline $\begin{array}{l}\text { Number of firms in } \\
\text { the financial sec- } \\
\text { tor/population }\end{array}$ & FINANCE_Firms & ISTAT, own elaboration & $\begin{array}{l}\text { Firm census (number of active units in the financial sec- } \\
\text { tor) and population data for year } 2011 \text {. }\end{array}$ \\
\hline Gender equality index & GEI & Amici and Stefani (2013) & $\begin{array}{l}\text { The indicator considers four dimensions: work (counting } \\
\text { both employment and unemployment), income, political } \\
\text { and economic representation and use of time. }\end{array}$ \\
\hline Mother housewife & HOUSEWIFE & OECD PISA (2012), own elaboration. & $\begin{array}{l}\text { Dummy variable equal to } 1 \text { if the mother's occupation } \\
\text { (as reported by student) is equal to "housewife" (ISCO } \\
\text { classification code } 9701 \text { ), and } 0 \text { otherwise. }\end{array}$ \\
\hline IGGI & IGGI & Bozzano (2012), own elaboration. & $\begin{array}{l}\text { Italian Gender Gap Index. The indicator is based on four } \\
\text { dimensions: The health and survival dimension, The ed- } \\
\text { ucational attainment dimension, The economic participa- } \\
\text { tion and opportunity dimension, The political participa- } \\
\text { tion dimension. We consider only two dimensions: eco- } \\
\text { nomic and political participation. }\end{array}$ \\
\hline Immigration status & IMMIGRANT & OECD PISA (2012) & $\begin{array}{l}\text { The student is either a second generation immigrant (born } \\
\text { in the country of assessment but whose parent(s) were } \\
\text { born in another country) or a first-generation immigrant } \\
\text { (born outside the country of assessment and whose parents } \\
\text { were also born in another country). }\end{array}$ \\
\hline $\begin{array}{l}\text { Other language spoken } \\
\text { at home }\end{array}$ & LANG_Foreign & OECD PISA (2012) & $\begin{array}{l}\text { Dummy variable equal to } 1 \text { if the language spoken at home } \\
\text { by the student is different with respect to the language of } \\
\text { assessment for that student, and } 0 \text { otherwise. }\end{array}$ \\
\hline
\end{tabular}




\begin{tabular}{|c|c|c|c|}
\hline Variable & Name of the Variable & Source & Definition \\
\hline Professional school & PROFESSIONAL SCHOOL & OECD PISA (2012), own elaboration. & school $=3$ \\
\hline $\begin{array}{l}\text { Projected \% of hirings for } \\
\text { people with an administra- } \\
\text { tive/commercial qualification } \\
\text { (at any level, from qualifica } \\
\text { professionale to laurea degree) }\end{array}$ & JOB_Adm & Excelsior survey & $\%$ over total projected hirings for year 2012 \\
\hline $\begin{array}{l}\text { Projected \% of hirings in the finan- } \\
\text { cial sector (non seasonal jobs) }\end{array}$ & JOB_Fin & Excelsior survey & $\%$ over total non seasonal projected hirings for year 2012 \\
\hline Large City Dummy & LARGE_CITY & OECD PISA (2012) & School is located in a city of $>1,000,000$ people \\
\hline Lyceums & LYCEUM & OECD PISA (2012), own elaboration. & school $=1$ \\
\hline $\begin{array}{l}\text { Number of lyceums per } 1,000 \text { in- } \\
\text { habitants }\end{array}$ & LYCEUMS per cap. & ISTAT & $\begin{array}{l}\text { Number of licei high school in the region in } 2011 \text { over total } \\
\text { population in 2011, multiplied by 1,000. }\end{array}$ \\
\hline Media sophistication index & MEDIA_Soph & ISTAT, own elaboration & $\begin{array}{l}\text { index of } \% \text { people watching tv, listening to radio, reading } \\
\text { newspaper (higher value }=\text { higher sophistication, i.e. more } \\
\text { news paper, more radio, less tv). Index created through } \\
\text { Principal Component Analysis of the three items above. } \\
\text { Data taken for year } 2012 \text {. }\end{array}$ \\
\hline Middle school & MIDDLE SCHOOL & OECD PISA (2012), own elaboration. & school $=4$ \\
\hline $\begin{array}{l}\text { Mother has a financial career } \\
\text { (broad definition) }\end{array}$ & MOTHER_Fin & OECD PISA (2012), own elaboration. & $\begin{array}{l}\text { This variable is equal to } 1 \text { if the mother's occupation (as } \\
\text { reported by student) is defined as a "managerial or fi- } \\
\text { nancial career" (see attached file on definition of financial } \\
\text { career). }\end{array}$ \\
\hline Nuclear Family Structure & NFS & Bertocchi et al. (2015) and Duranton (2007) & $\begin{array}{l}\text { Calculated as the number of provinces where, in the mid- } \\
\text { dle ages, the nuclear family was the prevailing family type } \\
\text { over total number of provinces in the region. The nuclear } \\
\text { family structure is defined as one where there is total } \\
\text { emancipation of children in adulthood to form indepen- } \\
\text { dent families made simply of a couple and their children. } \\
\text { (Todd, 1990)). }\end{array}$ \\
\hline Private school & PRIVATE SCHOOL & OECD PISA (2012) & As reported by the school principal. \\
\hline Proportion of girls in the school & PROP_Girl & OECD PISA (2012) & $\begin{array}{l}\text { The index of the proportion of girls at school is based } \\
\text { on the enrolment data provided by the school principal, } \\
\text { dividing the number of girls by the total number of girls } \\
\text { and boys at a school. }\end{array}$ \\
\hline Probability to save A & PSAVE_A & OECD PISA (2012) & $\begin{array}{l}\text { Variable equal to 1, if students answer "Which of these } \\
\text { statements about saving money best applies to you?" with } \\
\text { one of the following: "I save the same amount of money } \\
\text { each week or month," "I save some money each week or } \\
\text { month, but the amount varies," "I save money only when } \\
\text { I have some to spare," or "I save money only when I want } \\
\text { to buy something," and it is equal to } 0 \text { if the student } \\
\text { answers "I do not save any money." }\end{array}$ \\
\hline
\end{tabular}




\begin{tabular}{|c|c|c|c|}
\hline Variable & Name of the Variable & Source & Definition \\
\hline Probability to save B & PSAVE_B & OECD PISA (2012) & $\begin{array}{l}\text { Variable equal to } 1 \text { if students answer "save } \\
\text { money to buy" when asked "If you don't have } \\
\text { enough money to buy something you really } \\
\text { want (e.g. an item of clothing, sports equip- } \\
\text { ment) what are you most likely to do?". The } \\
\text { possible answer are buying the item anyway } \\
\text { with money that should be used for something } \\
\text { else; trying to borrow from a family member; } \\
\text { trying to borrow from a friend; not buying it. }\end{array}$ \\
\hline $\begin{array}{l}\text { Student repeated a } \\
\text { grade }\end{array}$ & REPEAT & OECD PISA (2012) & $\begin{array}{l}\text { Variable equal to } 1 \text { if student has repeated a } \\
\text { grade in at least one level of schooling and } \\
\text { equal to } 0 \text { if "No, never" was chosen at least one } \\
\text { time, given that none of the repeated grade } \\
\text { categories were chosen. The index is assigned } \\
\text { a missing value if none of the three categories } \\
\text { were ticked in any of three levels. }\end{array}$ \\
\hline Stereotype Index & Stereotype Index & ISTAT (2011) & $\begin{array}{l}\text { Derived from considering } 4 \text { questions of the IS- } \\
\text { TAT survey on discrimination by gender, sex- } \\
\text { ual orientation and ethnic origin. The survey } \\
\text { asks whether the interviewed agrees with the } \\
\text { statement } 1 \text {. "It is mainly the men that have } \\
\text { to take care of the economic needs of the fam- } \\
\text { ily"; } 2 \text {. "It is the man that takes the most rel- } \\
\text { evant decisions in the family."; } 3 \text {. "It is more } \\
\text { important for men than for women to have a } \\
\text { university degree"; } 4 \text {. "Men are less suitable } \\
\text { for household chores." }\end{array}$ \\
\hline $\begin{array}{l}\text { Percentage of math } \\
\text { teachers in the school }\end{array}$ & TEACH_Math & OECD PISA (2012) & $\begin{array}{l}\text { The percentage of mathematics teachers was } \\
\text { computed by dividing the number of mathe- } \\
\text { matics teachers by the total number of teach- } \\
\text { ers times } 100 \text {. Principals were asked to report } \\
\text { the number of full-time and part-time teach- } \\
\text { ers at their school. The number of part-time } \\
\text { teachers contributed } 0.5 \text { and the number of } \\
\text { full-time teachers } 1.0 \text { to the estimated num- } \\
\text { bers of teachers at school. }\end{array}$ \\
\hline $\begin{array}{l}\text { The teacher asks ques- } \\
\text { tions to check whether } \\
\text { we have understood } \\
\text { what was taught }\end{array}$ & TEACH_quest & OECD PISA (2012). & $\begin{array}{l}\text { The student was asked he following ques- } \\
\text { tion (ST79f): "How often does it happen in } \\
\text { your mathematics class that the teacher asks } \\
\text { questions to understand whether you under- } \\
\text { stood what was taught?" The possible answers } \\
\text { were "Every lesson"; "Most lessons"; "Some } \\
\text { lessons"; "Never or hardly ever". The vari- } \\
\text { able takes value } 1 \text { when the student replied } \\
\text { "Every lesson" or "Most lessons", } 0 \text { when the } \\
\text { student replied "Some lessons" or "Never or } \\
\text { hardly ever". }\end{array}$ \\
\hline $\begin{array}{l}\text { The teacher asks me } \\
\text { or my classmates to } \\
\text { present our thinking } \\
\text { or reasoning at some } \\
\text { length }\end{array}$ & TEACH_think & OECD PISA (2012). & $\begin{array}{l}\text { The student was asked the following question } \\
\text { (ST79b): "How often does it happen in your } \\
\text { mathematics class that the teacher asks you } \\
\text { or your classmates to present your thinking } \\
\text { or reasoning at some length?" The possible } \\
\text { answers were "Every lesson"; "Most lessons"; } \\
\text { "Some lessons"; "Never or hardly ever". The } \\
\text { variable takes value } 1 \text { when the student replied } \\
\text { "Every lesson" or "Most lessons", 0 when the } \\
\text { student replied "Some lessons" or "Never or } \\
\text { hardly ever". }\end{array}$ \\
\hline Technical school & TECHNICAL SCHOOL & OECD PISA (2012), own elaboration. & school $=2$ \\
\hline Vocational school & VOCATIONAL SCHOOL & OECD PISA (2012), own elaboration. & school $=5$ \\
\hline
\end{tabular}


Table A3: Descriptive Statistics of Individual-Level Variables, by Gender.

\begin{tabular}{|c|c|c|c|c|c|c|c|c|c|c|c|}
\hline \multirow[t]{2}{*}{ Variable } & \multirow[t]{2}{*}{ Name of the Variable } & \multicolumn{5}{|c|}{ Males } & \multicolumn{5}{|c|}{ Females } \\
\hline & & $\mathrm{N}$ & Mean & SD & Min & Max & $\mathrm{N}$ & Mean & SD & Min & Max \\
\hline Lyceums & LYCEUM & 2237 & 0.42 & 0.49 & 0 & 1 & 2414 & 0.67 & 0.47 & 0 & 1 \\
\hline Technical School & TECHNICAL SCHOOL & 2237 & 0.41 & 0.49 & 0 & 1 & 2414 & 0.20 & 0.40 & 0 & 1 \\
\hline Professional School & PROFESSIONAL SCHOOL & 2237 & 0.11 & 0.31 & 0 & 1 & 2414 & 0.10 & 0.30 & 0 & 1 \\
\hline Middle School & MIDDLE SCHOOL & 2237 & 0.02 & 0.13 & 0 & 1 & 2414 & 0.01 & 0.10 & 0 & 1 \\
\hline Vocational School & VOCATIONAL SCHOOL & 2237 & 0.05 & 0.21 & 0 & 1 & 2414 & 0.02 & 0.15 & 0 & 1 \\
\hline City Dummy & CITY & 2237 & 0.23 & 0.42 & 0 & 1 & 2414 & 0.21 & 0.41 & 0 & 1 \\
\hline Large City Dummy & LARGE CITY & 2237 & 0.04 & 0.19 & 0 & 1 & 2414 & 0.04 & 0.20 & 0 & 1 \\
\hline Age of student & $\mathrm{AGE}-$ & 2237 & 15.76 & 0.29 & 15.25 & 16.25 & 2414 & 15.76 & 0.29 & 15.25 & 16.25 \\
\hline Student repeated a grade & REPEAT & 2237 & 0.14 & 0.35 & 0 & 1 & 2414 & 0.08 & 0.28 & 0 & 1 \\
\hline Index of economic, social \& cultural status & ESCS & 2237 & 0.10 & 0.92 & -2 & 3 & 2414 & 0.05 & 0.94 & -2.44 & 2.53 \\
\hline Immigration status & IMMIGRANT & 2237 & 0.06 & 0.24 & 0 & 1 & 2414 & 0.06 & 0.23 & 0 & 1 \\
\hline Other language spoken at home & LANG_Foreign & 2237 & 0.20 & 0.40 & 0 & 1 & 2414 & 0.15 & 0.36 & 0 & 1 \\
\hline Private School & PRIVATE SCHOOL & 2237 & 0.05 & 0.22 & 0 & 1 & 2414 & 0.04 & 0.19 & 0 & 1 \\
\hline Proportion of girls in school & PROP_Girl & 2237 & 0.39 & 0.22 & 0.00 & 0.98 & 2414 & 0.59 & 0.19 & 0 & 1 \\
\hline Proportion of math teachers in school & TEACH_ Math & 2237 & 0.12 & 0.06 & 0 & 0 & 2414 & 0.12 & 0.05 & 0.01 & 0.33 \\
\hline Mother Housewife & HOUSEWIFE & 2237 & 0.18 & 0.38 & 0 & 1 & 2414 & 0.19 & 0.39 & 0 & 1 \\
\hline Mother has a financial career & MOTHER_Fin & 2237 & 0.05 & 0.21 & 0 & 1 & 2414 & 0.06 & 0.24 & 0 & 1 \\
\hline Father has a financial career & FATHER_Fin & 2237 & 0.06 & 0.24 & 0 & 1 & 2414 & 0.06 & 0.23 & 0 & 1 \\
\hline Parent expects a financial career & EXP_Fin & 1817 & 0.07 & 0.26 & 0 & 1 & 2013 & 0.05 & 0.22 & 0 & 1 \\
\hline
\end{tabular}




\section{Table A4:Descriptive Statistics of Regional-Level Variables}

\begin{tabular}{|c|c|c|c|c|c|c|}
\hline Variable & Name of the Variable & $\mathbf{N}$ & mean & sd & $\min$ & $\max$ \\
\hline Media Sophistication & MEDIA_Soph & 4651 & 0.15 & 1.58 & -2.05 & 2.97 \\
\hline Political Interest & POL_Tälk & 4651 & 15.68 & 2.26 & 11.20 & 19.80 \\
\hline Active Political Participation & $\mathrm{ACT}^{-} \mathrm{Pol}$ & 4651 & -0.02 & 1.28 & -1.70 & 3.37 \\
\hline Entrepreneur & ENTR & 4651 & 0.07 & 0.02 & 0.03 & 0.16 \\
\hline Bank Branches & BANKS & 4651 & 59.64 & 20.14 & 24.40 & 93.50 \\
\hline $\begin{array}{l}\text { Number of firms in the financial sec- } \\
\text { tor/population }\end{array}$ & FINANCE_Firms & 4651 & 0.08 & 0.02 & 0.05 & 0.19 \\
\hline $\begin{array}{l}\text { Projected } \% \text { of hirings in the financial sector } \\
\text { (non seasonal jobs) }\end{array}$ & JOB_Fin & 4651 & 0.02 & 0.01 & 0.01 & 0.04 \\
\hline $\begin{array}{l}\text { Projected } \% \text { of hirings for people with an ad- } \\
\text { ministrative/commercial qualification (at any } \\
\text { level, from qualifica professionale to laurea de- } \\
\text { gree) }\end{array}$ & JOB_Adm & 4651 & 0.14 & 0.03 & 0.09 & 0.19 \\
\hline Number of lyceums/thousand inhabitants & LYCEUMS per cap. & 4651 & 0.05 & 0.01 & 0.03 & 0.07 \\
\hline $\begin{array}{l}\% \text { of provinces which were on a medieval Com- } \\
\text { mercial route }\end{array}$ & COMM_Route & 4187 & 0.55 & 0.31 & 0 & 1 \\
\hline Nuclear family structure & NFS & 4651 & 0.54 & 0.48 & 0 & 1 \\
\hline
\end{tabular}


Table A5: Correlation between Main Variables

\begin{tabular}{|c|c|c|c|c|c|c|c|c|c|c|c|c|c|c|c|}
\hline Variables & (1) & $(2)$ & (3) & (4) & (5) & (6) & $(7)$ & $(8)$ & (9) & (10) & (11) & (12) & (13) & (14) & (15) \\
\hline (1) FEMALE & $\begin{array}{ll}1 \\
\end{array}$ & & & & & & & & & & & & & & \\
\hline (2) AGE & -0.0016 & 1 & & & & & & & & & & & & & \\
\hline (3) REPEAT & -0.095 & -0.0403 & 1 & & & & & & & & & & & & \\
\hline (4) ESCS & -0.0235 & 0.021 & -0.1403 & 1 & & & & & & & & & & & \\
\hline (5) IMMIGRANT & -0.0114 & -0.0273 & 0.112 & -0.1282 & 1 & & & & & & & & & & \\
\hline (6) LANG_Foreign & -0.0673 & -0.0002 & 0.0875 & -0.2254 & 0.2874 & 1 & & & & & & & & & \\
\hline (7) PRIVĀTE SCHOOL & -0.0332 & -0.0167 & 0.0495 & 0.0036 & 0.0116 & 0.0573 & 1 & & & & & & & & \\
\hline (8) City & -0.0212 & -0.005 & 0.0007 & 0.1083 & 0.0442 & -0.0465 & 0.0802 & 1 & & & & & & & \\
\hline (9) Large_City & 0.0092 & -0.0091 & 0.0059 & 0.1003 & -0.0168 & -0.0748 & 0.0049 & -0.1059 & 1 & & & & & & \\
\hline (10) PROP__Girl & 0.4255 & 0.0383 & -0.0918 & 0.0886 & -0.0362 & -0.0769 & -0.0919 & -0.039 & -0.01 & 1 & & & & & \\
\hline 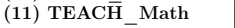 & 0.0183 & 0.0146 & -0.1547 & 0.2388 & -0.0264 & -0.1315 & 0.0074 & 0.0417 & 0.067 & 0.0925 & 1 & & & & \\
\hline 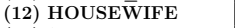 & 0.0129 & -0.0256 & 0.0356 & -0.3118 & 0.0549 & 0.0287 & -0.0209 & -0.0592 & -0.0147 & -0.0476 & -0.0700 & 1 & & & \\
\hline (13) Stereotype Index & 0.0122 & -0.0196 & -0.077 & -0.0711 & -0.0784 & -0.1042 & -0.1328 & -0.0733 & -0.0101 & 0.0176 & 0.0931 & 0.2373 & 1 & & \\
\hline (14) GEI & -0.0133 & 0.0242 & 0.0723 & 0.0826 & 0.0868 & 0.0774 & 0.107 & 0.055 & 0.0585 & -0.0195 & -0.0702 & -0.2355 & -0.9708 & 1 & \\
\hline (15) IGGI & -0.0147 & 0.0278 & 0.0704 & 0.0862 & 0.0812 & 0.0267 & 0.0961 & 0.0383 & 0.0716 & -0.0184 & -0.0574 & -0.2185 & -0.9463 & 0.9807 & 1 \\
\hline
\end{tabular}


Figure 1: Gender differences in Financial Literacy performance, before and after accounting for mathematics and reading performance.

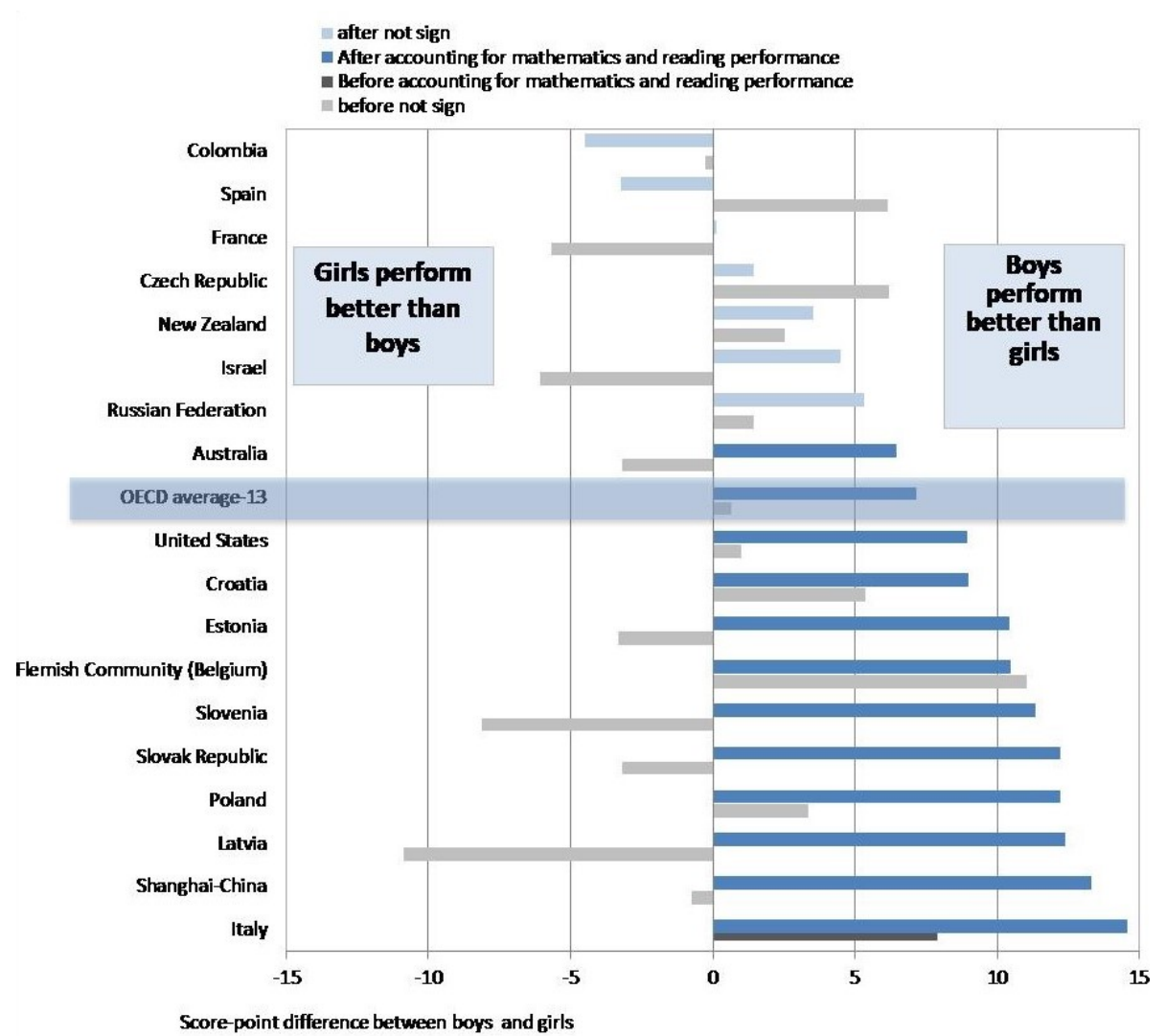

NOTE: Countries and economies are ranked in ascending order of the score-point difference in financial literacy performance between boys and girls, after accounting for mathematics and reading performance. 
Figure 2: Proficiency in Financial Literacy among Girls and Boys.

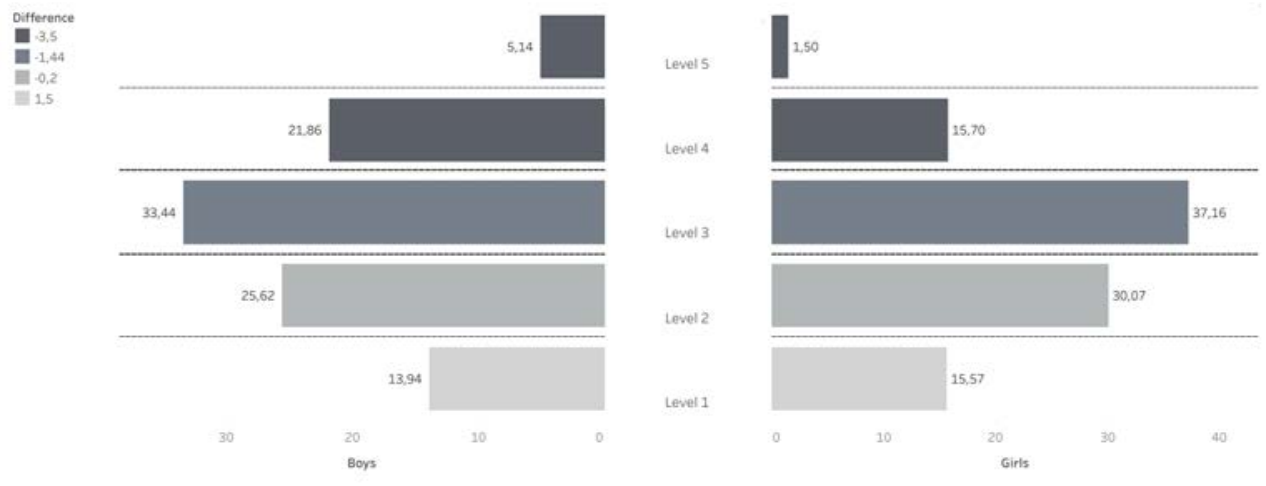

NOTE: The figure reports the average percentage of girls and boys by level of financial literacy proficiency. Level 5 is achieved by students with the highest score, Level 1 is achieved by students with the lowest score. The legend reports the average difference in the financial literacy score of girls and boys who achieved each level. 
Figure 3a: Difference in Financial Literacy Score between girls and boys.

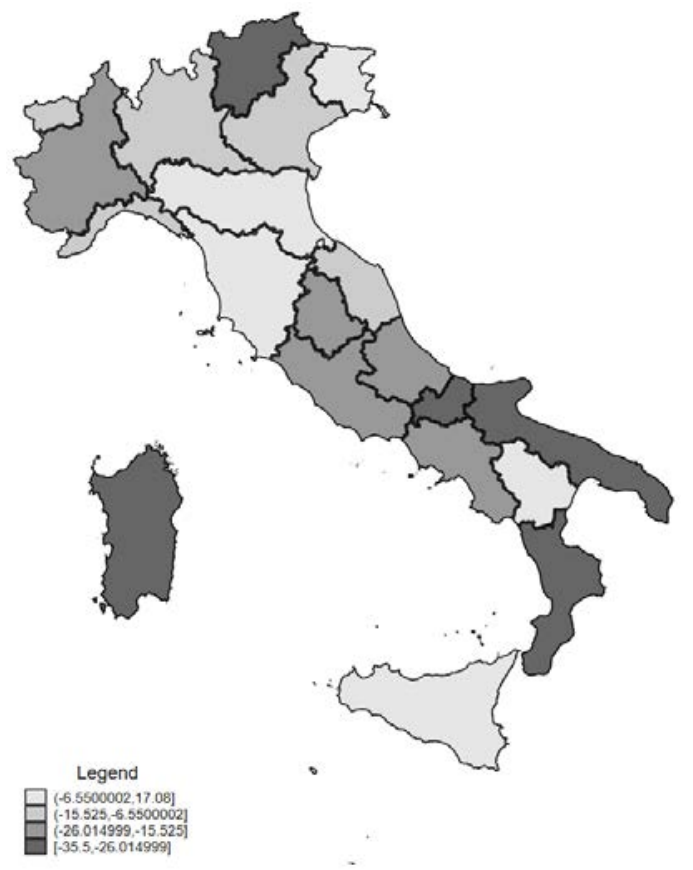

NOTE: The Figure reports the financial literacy gap between girls and boys by Region. Regions with darker color are those where the financial literacy gap between boys and girls is higher. Data Source: OECD

Figure 3b: Income per capita by Region

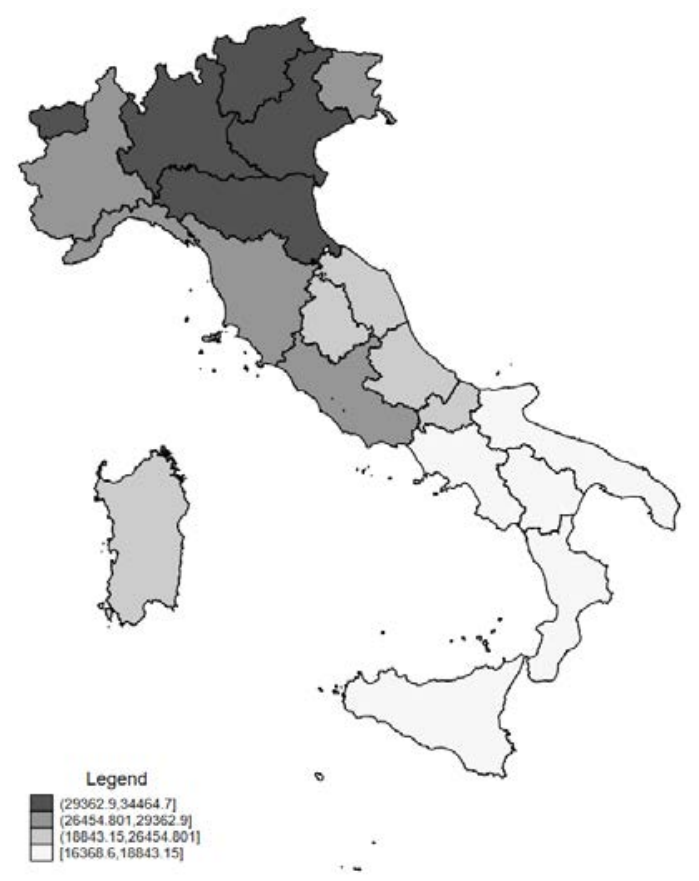

NOTE: The Figure reports the income per capita by region. Regions with darker color are those where the income per capita is higher. Data Source: ISTAT 


\section{Table 1: Regression with Student, School and City Characteristics.}

\begin{tabular}{|c|c|c|c|c|c|c|}
\hline Dependent Variable & $(1)$ & $(2)$ & (3) & $(4)$ & $(5)$ & (6) \\
\hline Financial Literacy Score & $\begin{array}{l}\text { Only region } \\
\text { dummies }\end{array}$ & $\begin{array}{l}\text { Basic student } \\
\text { controls }\end{array}$ & Italy: North-West & Italy: North-East & Italy: Center & Italy: South \& Islands \\
\hline FEMALE & $\begin{array}{c}-12.46^{* * *} \\
(-3.71)\end{array}$ & $\begin{array}{c}-18.96^{* * *} \\
(-5.67)\end{array}$ & $\begin{array}{c}-15.84^{* *} \\
(-2.06)\end{array}$ & $\begin{array}{c}-12.71^{* * *} \\
(-2.07)\end{array}$ & $\begin{array}{c}16.72^{* * * *} \\
(-3.02)\end{array}$ & $\begin{array}{c}-24.67^{* * * *} \\
(-6.13)\end{array}$ \\
\hline TECHNICAL SCHOOL & & $\begin{array}{c}-21.88^{* * * *} \\
(-4.05)\end{array}$ & $\begin{array}{l}-14.32 \\
(-1.34)\end{array}$ & $\begin{array}{c}-7.02 \\
(-0.78)\end{array}$ & $\begin{array}{c}-27.20^{* *} \\
(-2.30)\end{array}$ & $\begin{array}{c}-30.38^{* * *} \\
(-3.06)\end{array}$ \\
\hline PROFESSIONAL SCHOOL & & $\begin{array}{c}-62.3 * * * \\
(-7.26)\end{array}$ & $\begin{array}{c}-73.17^{* * * *} \\
(-4.33)\end{array}$ & $\begin{array}{c}-50.74 * * * \\
(-2.90)\end{array}$ & $\begin{array}{c}-55.60^{* * *} \\
(-3.52)\end{array}$ & $\begin{array}{c}-65.37^{* * * *} \\
(-4.80)\end{array}$ \\
\hline MIDDLE SCHOOL & & $\begin{array}{c}-48.20^{* *} \\
(-2.20)\end{array}$ & $\begin{array}{c}-120.29^{* * * *} \\
(-5.88)\end{array}$ & $\begin{array}{c}-137.27^{* * * *} \\
(-3.03)\end{array}$ & $\begin{array}{c}-43.15^{*} \\
(-1.82)\end{array}$ & $\begin{array}{l}-10.28 \\
(-0.33)\end{array}$ \\
\hline VOCATIONAL SCHOOL & & $\begin{array}{c}-71.57^{* * * *} \\
(-6.51)\end{array}$ & $\begin{array}{c}-95.37^{* * *} \\
(-6.22)\end{array}$ & $\begin{array}{c}-62.02^{* * *} \\
(-3.66)\end{array}$ & $\begin{array}{c}-54.69^{* * * *} \\
(-2.99)\end{array}$ & $\begin{array}{c}-177.62^{* * * *} \\
(-10.15)\end{array}$ \\
\hline $\mathrm{AGE}$ & & $\begin{array}{c}11.70^{* *} \\
(2.03)\end{array}$ & $\begin{array}{l}11.39 \\
(1.03)\end{array}$ & $\begin{array}{c}3.36 \\
(0.41)\end{array}$ & $\begin{array}{c}4.60 \\
(0.39)\end{array}$ & $\begin{array}{c}16.45^{* *} \\
(2.09)\end{array}$ \\
\hline REPEAT & & $\begin{array}{c}-40.38^{* * * *} \\
(-8.41)\end{array}$ & $\begin{array}{l}-19.47^{* *} \\
(-2.07)\end{array}$ & $\begin{array}{c}-36.29^{* * * *} \\
(-4.33)\end{array}$ & $\begin{array}{c}-57.64^{* * * *} \\
(-6.54)\end{array}$ & $\begin{array}{c}-50.47^{* * * *} \\
(-5.67)\end{array}$ \\
\hline ESCS & & $\begin{array}{l}3.92^{* *} \\
(2.27)\end{array}$ & $\begin{array}{c}0.80 \\
(0.23)\end{array}$ & $\begin{array}{l}-1.13 \\
(-0.35)\end{array}$ & $\begin{array}{c}2.64 \\
(0.84)\end{array}$ & $\begin{array}{c}8.85^{* * * *} \\
(3.26)\end{array}$ \\
\hline IMMIGRANT & & $\begin{array}{l}-15.43^{* *} \\
(-2.10)\end{array}$ & $\begin{array}{c}6.89 \\
(0.53)\end{array}$ & $\begin{array}{l}-21.42^{*} \\
(-1.77)\end{array}$ & $\begin{array}{l}-17.66^{*} \\
(-1.80)\end{array}$ & $\begin{array}{l}-10.44 \\
(-0.68)\end{array}$ \\
\hline LANG_Foreign & & $\begin{array}{c}-10.24^{*} \\
(-1.76)\end{array}$ & $\begin{array}{c}-57.35^{* * * *} \\
(-3.34)\end{array}$ & $\begin{array}{c}-9.37 \\
(-1.06)\end{array}$ & $\begin{array}{l}-6.37 \\
(-0.57)\end{array}$ & $\begin{array}{l}1.07 \\
(0.11)\end{array}$ \\
\hline PRIVATE SCHOOL & & $\begin{array}{c}-20.53^{* *} \\
(-2.07)\end{array}$ & $\begin{array}{l}-14.82 \\
(-0.77)\end{array}$ & $\begin{array}{l}-20.31 \\
(-1.38)\end{array}$ & $\begin{array}{l}-17.18 \\
(-0.83)\end{array}$ & $\begin{array}{c}-0.67 \\
(-0.06)\end{array}$ \\
\hline CITY & & $\begin{array}{c}2.43 \\
(0.51)\end{array}$ & $\begin{array}{l}-1.30 \\
(-0.10)\end{array}$ & $\begin{array}{c}0.18 \\
(0.03)\end{array}$ & $\begin{array}{l}10.22 \\
(1.15)\end{array}$ & $\begin{array}{l}1.23 \\
(0.15)\end{array}$ \\
\hline LARGE CITY & & $\begin{array}{l}-2.44 \\
(-0.24)\end{array}$ & $\begin{array}{c}0.09 \\
(0.01)\end{array}$ & & $\begin{array}{l}1.94 \\
(0.19)\end{array}$ & $\begin{array}{l}-19.61 \\
(-0.99)\end{array}$ \\
\hline PROP_Girls & & $\begin{array}{l}-16.21^{*} \\
(-1.71)\end{array}$ & $\begin{array}{c}4.85 \\
(0.28)\end{array}$ & $\begin{array}{l}-12.22 \\
(-0.75)\end{array}$ & $\begin{array}{l}-35.24 \\
(-1.52)\end{array}$ & $\begin{array}{l}-22.26 \\
(-1.30)\end{array}$ \\
\hline TEACH_Math & & $\begin{array}{c}1.96^{* * * *} \\
(4.48)\end{array}$ & $\begin{array}{c}0.52 \\
(0.70)\end{array}$ & $\begin{array}{c}2.16^{* * * *} \\
(2.59)\end{array}$ & $\begin{array}{c}2.98^{* * * *} \\
(3.53)\end{array}$ & $\begin{array}{c}2.50^{* * * *} \\
(3.03)\end{array}$ \\
\hline HOUSEWIFE & & $\begin{array}{c}-18.76^{* * *} \\
(-4.39) \\
\end{array}$ & $\begin{array}{c}-20.20^{* *} \\
(-2.17)\end{array}$ & $\begin{array}{c}-20.70^{* *} \\
(-2.33)\end{array}$ & $\begin{array}{c}-18.16^{* *} \\
(-2.26)\end{array}$ & $\begin{array}{c}-13.35 * * \\
(-2.40)\end{array}$ \\
\hline Region dummies & YES & YES & YES & YES & YES & YES \\
\hline Adjusted_R2 & 0.09 & 0.36 & 0.34 & 0.30 & 0.35 & 0.33 \\
\hline & 4651 & 4651 & 806 & 1273 & 912 & 1660 \\
\hline Omitted region & & & Liguria & Alto Adige & Umbria & Basilicata \\
\hline \multicolumn{7}{|c|}{$\begin{array}{l}\text { NOTE: The table reports our basic specification for the whole country and for different macro regions. Column (1) include controls for region fixed ef- } \\
\text { fects. Column }(2) \text { includes region's fixed effects and our basic control variables. Columns }(3),(4) \text {, (5) and (6) shows our basic specification for dif- } \\
\text { ferent macro geographical areas. REPEAT is a dummy variable equal to } 1 \text { if the student has repeated a grade. ESCS is an index of student's } \\
\text { economic, social and cultural status; LANG_Foreign is equal to } 1 \text { if the language spoken at home is not the Italian language; PROP_Girls indi- } \\
\text { cates the Proportion of girls enrolled in the school; TEACH_Math is the percentage of Math Teachers in school; HOUSEWIFE is a dummy vari- } \\
\text { able equal to } 1 \text { if the mother is a housewife. The T-statistics computed with robust standard errors are in parenthesis below the coefficients. } \\
* * * p<0.01, * * p<0.05,{ }^{*} p<0.1\end{array}$} \\
\hline
\end{tabular}


Table 2: Quantile regressions with Student Basic Controls.

\begin{tabular}{|c|c|c|c|c|c|}
\hline Dependent Variables & (1) & $(2)$ & (3) & $(4)$ & $(5)$ \\
\hline Financial Literacy Score & 10th pctl & 25 th pctl & 50th pctl & 75th pctl & 90th pctl \\
\hline FEMALE & $\begin{array}{c}-15.81^{* *} \\
(-1.96)\end{array}$ & $\begin{array}{c}-14.48^{* * *} \\
(-2.62)\end{array}$ & $\begin{array}{c}-16.04^{* * *} \\
(-2.78)\end{array}$ & $\begin{array}{c}-23.42^{* * *} \\
(-5.47)\end{array}$ & $\begin{array}{c}-25.99^{* * *} \\
(-4.22)\end{array}$ \\
\hline AGE & $\begin{array}{l}10.74 \\
(0.81)\end{array}$ & $\begin{array}{c}10.99 \\
(1.2)\end{array}$ & $\begin{array}{c}9.64 \\
(1.43)\end{array}$ & $\begin{array}{c}13.58^{*} \\
(1.9)\end{array}$ & $\begin{array}{l}12.68 \\
(0.89)\end{array}$ \\
\hline REPEAT & $\begin{array}{c}-35.77^{* * *} \\
(-2.96)\end{array}$ & $\begin{array}{c}-37.91 * * * \\
(-3.89)\end{array}$ & $\begin{array}{c}-42.97^{* * *} \\
(-6.04)\end{array}$ & $\begin{array}{c}-43.71^{* * *} \\
(-5.62)\end{array}$ & $\begin{array}{c}-40.79 * * * \\
(-3.71)\end{array}$ \\
\hline ESCS & $\begin{array}{c}3.98 \\
(0.78)\end{array}$ & $\begin{array}{c}3.8 \\
(1.3)\end{array}$ & $\begin{array}{c}3.28 \\
(1.23)\end{array}$ & $\begin{array}{c}3.92 \\
(1.44)\end{array}$ & $\begin{array}{c}7.75^{*} \\
(1.93)\end{array}$ \\
\hline IMMIGRANT & $\begin{array}{l}-19.26 \\
(-1.05)\end{array}$ & $\begin{array}{l}-17.11 \\
(-0.99)\end{array}$ & $\begin{array}{l}-13.58 \\
(-1.15)\end{array}$ & $\begin{array}{c}-10.58 \\
(-0.8)\end{array}$ & $\begin{array}{c}-9.95 \\
(-0.98)\end{array}$ \\
\hline LANG_Foreign & $\begin{array}{l}-11.4 \\
(-0.97)\end{array}$ & $\begin{array}{l}-10.39 \\
(-0.99)\end{array}$ & $\begin{array}{l}-12.44 \\
(-1.48)\end{array}$ & $\begin{array}{l}-11.1 \\
(-1.4)\end{array}$ & $\begin{array}{l}-8.68 \\
(-0.91)\end{array}$ \\
\hline PRIVATE SCHOOL & $\begin{array}{l}-33.36 \\
(-1.23)\end{array}$ & $\begin{array}{c}-30.47 \\
(-1.2)\end{array}$ & $\begin{array}{l}-18.67 \\
(-1.47)\end{array}$ & $\begin{array}{c}-19.67 \\
(-1.5)\end{array}$ & $\begin{array}{l}-19.41 \\
(-1.31)\end{array}$ \\
\hline PROP_Girls & $\begin{array}{l}-13.1 \\
(-0.66)\end{array}$ & $\begin{array}{l}-4.59 \\
(-0.28)\end{array}$ & $\begin{array}{l}-16.67 \\
(-1.28)\end{array}$ & $\begin{array}{c}-24.91^{*} \\
(-1.88)\end{array}$ & $\begin{array}{l}-17.68 \\
(-0.84)\end{array}$ \\
\hline PROP_Math & $\begin{array}{l}1.92^{* *} \\
(2.56)\end{array}$ & $\begin{array}{c}1.97^{* * *} \\
(2.63)\end{array}$ & $\begin{array}{c}1.98^{* * *} \\
(3.27)\end{array}$ & $\begin{array}{c}2.26^{* * * *} \\
(4.11)\end{array}$ & $\begin{array}{c}2.12^{* * *} \\
(2.58)\end{array}$ \\
\hline HOUSEWIFE & $\begin{array}{c}-18.58^{*} \\
(-1.95) \\
\end{array}$ & $\begin{array}{c}-18.06^{* *} \\
(-2.54)\end{array}$ & $\begin{array}{c}-19.38 * * * \\
(-3.21) \\
\end{array}$ & $\begin{array}{c}-16.2^{* *} \\
(-2.29) \\
\end{array}$ & $\begin{array}{c}-15.22^{*} \\
(-1.92) \\
\end{array}$ \\
\hline Region dummies & YES & YES & YES & YES & YES \\
\hline School dummies & YES & YES & YES & YES & YES \\
\hline School location dummies & YES & YES & YES & YES & YES \\
\hline $\mathrm{N}$ & 4651 & 4651 & 4651 & 4651 & 4651 \\
\hline
\end{tabular}


Table 3: The Effect of Parents' Financial Career.

\begin{tabular}{lcccc}
\hline Dependent Variable & $\mathbf{( 1 )}$ & $\mathbf{( 2 )}$ & $\mathbf{( 3 )}$ & $\mathbf{( 4 )}$ \\
\hline Financial Literacy Score & & & & \\
\hline FEMALE & $-19.14^{* * *}$ & $-20.19^{* * *}$ & female=1 & female $=0$ \\
& $(-5.72)$ & $(3.36)$ & & \\
MOTHER_Fin & 6.09 & -5.96 & $15.66^{* *}$ & -7.58 \\
& $(0.95)$ & $(0.95)$ & $(2.01)$ & $(-0.84)$ \\
FATHER_Fin & -4.28 & -4.11 & -0.81 & -5.18 \\
& $(-0.81)$ & $(7.79)$ & $(-0.11)$ & $(-0.71)$ \\
MOTHER_Fin*FEMALE & & 19.93 & & \\
& & $(10.71)$ & & \\
FATHER_Fin*FEMALE & & 0.3 & & \\
& & $(11.43)$ & & \\
\hline Region dummies & YES & YES & YES & YES \\
School dummies & YES & YES & YES & YES \\
Basic student controls & YES & YES & YES & YES \\
Adjusted_R2 & 0.36 & 0.36 & 0.35 & 0.37 \\
N & 4651 & 4651 & 2414 & 2237 \\
\hline
\end{tabular}

NOTE: The table shows the importance of mother's and father's financial or managerial careers on students' financial literacy score. Column (1) reports our basic specification adding financial career for both parents.

In column (2) we replicate the previous regression adding interactions with the FEMALE variable. In column (3) and (4) we perform the regression with sub-sample of males and females respectively. MOTHER_Fin and FATHER Fin are dummy variables equal to 1 if mother's and father's occupation is "managerial or financial". The T-statistics computed with robust standard errors are in parenthesis below the coefficients. $* * * \mathrm{p}<0.01,{ }^{*} \mathrm{p}<0.05,{ }^{*} \mathrm{p}<0.1$ 
Table 4a: The Effect of the Regional Environment.

\begin{tabular}{|c|c|c|c|c|c|c|c|c|}
\hline Dependent Variable & (1) & $(2)$ & (3) & (4) & (5) & (6) & $(7)$ & (8) \\
\hline \multicolumn{9}{|l|}{ Financial Literacy Score } \\
\hline FEMALE & $\begin{array}{l}-19.22 \\
(-5.60)\end{array}$ & $\begin{array}{c}-35.37^{* * *} \\
(-2.25)\end{array}$ & $\begin{array}{c}-20.20^{* * *} \\
(-6.14)\end{array}$ & $\begin{array}{c}-36.67 * * * \\
(-3.95)\end{array}$ & $\begin{array}{c}35.82^{* * *} * \\
(-4.84)\end{array}$ & $\begin{array}{c}-52.15^{* * *} \\
(-3.65)\end{array}$ & $\begin{array}{c}-34.53^{* *} \\
(-4.18)\end{array}$ & $\begin{array}{c}-51.84^{* * *} \\
(-3.24)\end{array}$ \\
\hline MEDIA_Soph & $\begin{array}{c}0.90 \\
(0.36)\end{array}$ & $\begin{array}{c}2.60 \\
(1.18)\end{array}$ & $\begin{array}{c}2.62 \\
(1.20)\end{array}$ & $\begin{array}{c}2.65 \\
(1.21)\end{array}$ & $\begin{array}{c}2.56 \\
(1.16)\end{array}$ & $\begin{array}{c}2.71 \\
(1.24)\end{array}$ & $\begin{array}{c}2.47 \\
(1.22)\end{array}$ & $\begin{array}{c}1.13 \\
(0.51)\end{array}$ \\
\hline POL_Talk & $\begin{array}{l}1.22 \\
(1.04)\end{array}$ & $\begin{array}{c}0.68 \\
(0.52)\end{array}$ & $\begin{array}{l}1.22 \\
(1.05)\end{array}$ & $\begin{array}{c}1.20 \\
(1.03)\end{array}$ & $\begin{array}{c}1.22 \\
(1.05)\end{array}$ & $\begin{array}{c}1.15 \\
(0.99)\end{array}$ & $\begin{array}{c}1.27 \\
(1.17)\end{array}$ & $\begin{array}{c}2.05 \\
(1.74)\end{array}$ \\
\hline ACT_Pol & $\begin{array}{c}-5.45^{* * *} \\
(-3.26)\end{array}$ & $\begin{array}{c}-5.42^{* * *} \\
(-3.24)\end{array}$ & $\begin{array}{l}-3.32 \\
(-1.54)\end{array}$ & $\begin{array}{c}-5.42 * * * \\
(-3.23)\end{array}$ & $\begin{array}{c}-5.45^{* * *} \\
(-3.26)\end{array}$ & $\begin{array}{c}-5.42^{* * *} \\
(-3.24)\end{array}$ & $\begin{array}{c}-5.47 * * * \\
(-3.29)\end{array}$ & $\begin{array}{c}-4.89^{* * *} * \\
(-2.91)\end{array}$ \\
\hline ENTR & $\begin{array}{c}0.44 \\
(0.43)\end{array}$ & $\begin{array}{c}0.43 \\
(0.41)\end{array}$ & $\begin{array}{c}0.45 \\
(0.43)\end{array}$ & $\begin{array}{l}-0.91 \\
(-0.70)\end{array}$ & $\begin{array}{c}0.47 \\
(0.45)\end{array}$ & $\begin{array}{c}0.49 \\
(0.47)\end{array}$ & $\begin{array}{c}0.44 \\
(0.42)\end{array}$ & $\begin{array}{c}-1.51 \\
(-1.24)\end{array}$ \\
\hline BANKS & $\begin{array}{c}0.80^{* * *} \\
(4.19)\end{array}$ & $\begin{array}{c}0.81 * * * \\
(4.21)\end{array}$ & $\begin{array}{c}0.81^{* * * *} \\
(4.22)\end{array}$ & $\begin{array}{c}0.80^{* * *} \\
(4.14)\end{array}$ & $\begin{array}{c}0.66^{* * *} \\
(3.48)\end{array}$ & $\begin{array}{c}0.79^{* * *} \\
(4.11)\end{array}$ & $\begin{array}{c}0.81^{* * *} \\
(4.40)\end{array}$ & $\begin{array}{c}0.79^{* * *} \\
(4.07)\end{array}$ \\
\hline FINANCE_Firms & $\begin{array}{l}-0.27 \\
(-0.15)\end{array}$ & $\begin{array}{l}-0.31 \\
(-0.17)\end{array}$ & $\begin{array}{l}-0.31 \\
(-0.17)\end{array}$ & $\begin{array}{l}-0.06 \\
(-0.03)\end{array}$ & $\begin{array}{l}-0.31 \\
(-0.17)\end{array}$ & $\begin{array}{l}-2.28 \\
(-1.12)\end{array}$ & $\begin{array}{l}-0.45 \\
(-0.33)\end{array}$ & $\begin{array}{l}-1.11 \\
(-0.64)\end{array}$ \\
\hline JOB_Fin & & & & & & & $\begin{array}{l}-2.86 \\
(-0.78)\end{array}$ & \\
\hline JOB_Adm & & & & & & & & $\begin{array}{c}1.23 \\
(1.14)\end{array}$ \\
\hline MEDIA_Soph*FEMALE & $\begin{array}{l}3.34^{*} \\
(1.72)\end{array}$ & & & & & & & \\
\hline POL_Talk*FEMALE & & $\begin{array}{c}1.05 \\
(1.02)\end{array}$ & & & & & & \\
\hline ACT_Pol*FEMALE & & & $\begin{array}{l}-4.07^{*} \\
(-1.85)\end{array}$ & & & & & \\
\hline ENTR*FEMALE & & & & $\begin{array}{l}2.50^{*} \\
(1.9)\end{array}$ & & & & \\
\hline BANKS*FEMALE & & & & & $\begin{array}{l}0.30^{* *} \\
(2.32)\end{array}$ & & & \\
\hline FINAN_Firms*FEMALE & & & & & & $\begin{array}{l}4.44^{* *} \\
(2.27)\end{array}$ & & \\
\hline JOB_Fin*FEMALE & & & & & & & $\begin{array}{l}6.40^{*} \\
(1.69)\end{array}$ & \\
\hline JOB_Adm*FEMALE & & & & & & & & $\begin{array}{l}2.23^{*} \\
(1.95)\end{array}$ \\
\hline Region dummies & NO & NO & NO & NO & NO & NO & NO & $\mathrm{NO}$ \\
\hline School dummies & YES & YES & YES & YES & YES & YES & YES & YES \\
\hline Basic student controls & YES & YES & YES & YES & YES & YES & YES & YES \\
\hline Adjusted R2 & 0.35 & 0.35 & 0.35 & 0.35 & 0.35 & 0.35 & 0.35 & 0.35 \\
\hline $\mathrm{N}$ & 4651 & 4561 & 4651 & 4651 & 4561 & 4561 & 4561 & 4561 \\
\hline
\end{tabular}

NOTE: The table shows the impact of the regional environment characteristics and their interaction with FEMALE on students ${ }^{6}$ financial literacy score. MEDIA_Soph is a regional level index of the \% of people watching TV, listening to radio, reading newspapers; POL_Talk indicates the \% of people who talk about politics at the regional level; ACT_Pol indicates the \% of people who attend political events at the regional level; ENTR is the proportion of entrepreneurs over the total regional population; BANKS is the number of banks for every 1000 inhabitants in the region; FINANCE Firms is the number of financial firms over the total regional population; JOB Fin is the projected \% of hirings in the financial sector at the regional level; JOB Adm is the projected \% of hirings for people with administrative/commercial qualification at the regional level. T-statistics computed with robust standard errors are in parenthesis below the coefficients. $* * * \mathrm{p}<0.01,{ }^{* *} \mathrm{p}<0.05,{ }^{*} \mathrm{p}<0.1$ 


\section{Table 4b: Historical Determinants of the Local Environment.}

\begin{tabular}{|c|c|c|c|c|c|}
\hline Dependent Variable & (1) & $(2)$ & $(3)$ & (4) & $(5)$ \\
\hline \multicolumn{6}{|l|}{ Financial Literacy Score } \\
\hline FEMALE & $\begin{array}{c}-41.23^{* * *} \\
(-3.82)\end{array}$ & $\begin{array}{c}-18.51^{* * *} \\
(-3.79)\end{array}$ & $\begin{array}{l}22.20^{* * * *} \\
(1.09)\end{array}$ & $\begin{array}{c}-47.09 * * * \\
(-3.56)\end{array}$ & $\begin{array}{l}-90.88^{* *} \\
(-2.52)\end{array}$ \\
\hline COMM_Route & $\begin{array}{c}4.07^{* * *} \\
(9.22)\end{array}$ & & & & \\
\hline COMM_Route*FEMALE & $\begin{array}{c}0.42^{* * *} \\
(1.97)\end{array}$ & & & & \\
\hline NFS & & $\begin{array}{c}-0.52^{* * *} \\
(-4.45)\end{array}$ & & & \\
\hline NFS*FEMALE & & $\begin{array}{l}-0.01 \\
(-0.11)\end{array}$ & & & \\
\hline Stereotype Index & & & $\begin{array}{l}-8.96^{* * *} \\
(-8.98)\end{array}$ & & \\
\hline Steretype Index*FEMALE & & & $\begin{array}{l}-1.30 * * \\
(-2.15)\end{array}$ & & \\
\hline GEI & & & & $\begin{array}{l}6.28 * * * \\
(9.11)\end{array}$ & \\
\hline GEI*FEMALE & & & & $\begin{array}{l}0.78^{* *} \\
(2.04)\end{array}$ & \\
\hline IGGI & & & & & $\begin{array}{l}15.45^{* * *} \\
(9.25)\end{array}$ \\
\hline IGGI*FEMALE & & & & & $\begin{array}{l}1.55^{*} \\
(1.95)\end{array}$ \\
\hline Region dummies & YES & YES & YES & YES & YES \\
\hline School dummies & YES & YES & YES & YES & YES \\
\hline Basic student dummies & YES & YES & YES & YES & YES \\
\hline Adjusted R2 & 0.36 & 0.36 & 0.36 & 0.36 & 0.36 \\
\hline $\mathrm{N}$ & 4651 & 4651 & 4651 & 4651 & 4651 \\
\hline
\end{tabular}


Table 5: Financial Literacy at different Quantiles of Math Literacy.

\begin{tabular}{|c|c|c|c|c|c|}
\hline Dependent Variables & (1) & $(2)$ & (3) & (4) & (5) \\
\hline Financial Literacy Score & 10th pctl & 25 th pctl & 50 th pctl & 75th pctl & 90th pctl \\
\hline FEMALE & $\begin{array}{c}-17.00^{* * *} \\
(-4.85)\end{array}$ & $\begin{array}{c}-13.61^{* * *} \\
(-3.81)\end{array}$ & $\begin{array}{c}-13.15^{* * *} \\
(-3.62)\end{array}$ & $\begin{array}{l}-9.26^{*} \\
(-1.84)\end{array}$ & $\begin{array}{l}-10.3 \\
(-1.33)\end{array}$ \\
\hline TECHNICAL SCHOOL & $\begin{array}{c}-19.97^{* * *} \\
(-3.64)\end{array}$ & $\begin{array}{c}-17.42^{* * *} \\
(-3.33)\end{array}$ & $\begin{array}{l}-10.29 \\
(-1.62)\end{array}$ & $\begin{array}{l}-5.14 \\
(-0.6)\end{array}$ & $\begin{array}{c}-2.64 \\
(-0.19)\end{array}$ \\
\hline PROFESSIONAL SCHOOL & $\begin{array}{c}-53.75^{* * *} \\
(-6.27)\end{array}$ & $\begin{array}{c}-50.22^{* * *} \\
(-5.61)\end{array}$ & $\begin{array}{c}-28.15^{* *} \\
(-2.34)\end{array}$ & $\begin{array}{l}-13.97 \\
(-0.63)\end{array}$ & $\begin{array}{c}-5.85 \\
(-0.37)\end{array}$ \\
\hline MIDDLE SCHOOL & $\begin{array}{c}-30.99^{* *} \\
(-2.19)\end{array}$ & $\begin{array}{l}-14.81 \\
(-0.87)\end{array}$ & $\begin{array}{c}-18.14 \\
(-0.99)\end{array}$ & $\begin{array}{l}-4.41 \\
(-0.23)\end{array}$ & (omitted) \\
\hline VOCATIONAL SCHOOL & $\begin{array}{c}-57.45^{* * *} \\
(-5.49)\end{array}$ & $\begin{array}{c}-45.55^{* * *} \\
(-4.12)\end{array}$ & $\begin{array}{c}-28.9 \\
(-1.49)\end{array}$ & $\begin{array}{c}-42.56^{* *} \\
(-2.36)\end{array}$ & $\begin{array}{c}10.4 \\
(0.37)\end{array}$ \\
\hline AGE & $\begin{array}{c}11.64^{*} \\
(1.94)\end{array}$ & $\begin{array}{c}7.36 \\
(1.27)\end{array}$ & $\begin{array}{c}11.50^{*} \\
(1.88)\end{array}$ & $\begin{array}{c}19.76^{* * *} \\
(2.89)\end{array}$ & $\begin{array}{c}13.76 \\
(1.30)\end{array}$ \\
\hline REPEAT & $\begin{array}{c}-38.60 * * * \\
(-7.79)\end{array}$ & $\begin{array}{c}-33.51^{* * *} \\
(-6.19)\end{array}$ & $\begin{array}{c}-36.64 * * * \\
(-4.58)\end{array}$ & $\begin{array}{c}-29.45^{* *} \\
(-2.42)\end{array}$ & $\begin{array}{c}-36.04^{* *} \\
(-2.46)\end{array}$ \\
\hline ESCS & $\begin{array}{c}4.6 \\
(2.68)\end{array}$ & $\begin{array}{c}4.12^{* *} \\
(2.38)\end{array}$ & $\begin{array}{c}2.59 \\
(1.36)\end{array}$ & $\begin{array}{c}0.67 \\
(0.24)\end{array}$ & $\begin{array}{c}-3.63 \\
(-0.83)\end{array}$ \\
\hline IMMIGRANT & $\begin{array}{r}-8.97 \\
(-1.24)\end{array}$ & $\begin{array}{l}-10.42 \\
(-1.35)\end{array}$ & $\begin{array}{c}-6.1 \\
(-0.67)\end{array}$ & $\begin{array}{l}-9.26 \\
(-0.91)\end{array}$ & $\begin{array}{c}-27.81^{* *} \\
(-2.2)\end{array}$ \\
\hline LANG_Foreign & $\begin{array}{c}-7.98 \\
(-1.64)\end{array}$ & $\begin{array}{l}-9.63^{*} \\
(-1.94)\end{array}$ & $\begin{array}{l}-10.8^{*} \\
(-1.69)\end{array}$ & $\begin{array}{l}1.16 \\
(0.13)\end{array}$ & $\begin{array}{l}-17.39 \\
(-1.15)\end{array}$ \\
\hline PRIVATE SCHOOL & $\begin{array}{l}-27.3^{* *} \\
(-2.51)\end{array}$ & $\begin{array}{c}-30.84^{* *} \\
(-2.43)\end{array}$ & $\begin{array}{c}-27.41^{*} \\
(-1.67)\end{array}$ & $\begin{array}{l}-13.27 \\
(-1.27)\end{array}$ & $\begin{array}{l}-1.56 \\
(-0.12)\end{array}$ \\
\hline CITY & $\begin{array}{c}1.66 \\
(0.37)\end{array}$ & $\begin{array}{l}-0.25 \\
(-0.05)\end{array}$ & $\begin{array}{c}1.2 \\
(0.25)\end{array}$ & $\begin{array}{c}4.84 \\
(0.84)\end{array}$ & $\begin{array}{c}17.76^{* *} \\
(2.04)\end{array}$ \\
\hline LARGE CITY & $\begin{array}{c}-3.68 \\
(-0.37)\end{array}$ & $\begin{array}{l}-1.74 \\
(-0.18)\end{array}$ & $\begin{array}{l}1.53 \\
(0.14)\end{array}$ & $\begin{array}{c}13.65 \\
(0.88)\end{array}$ & $\begin{array}{l}-14.13 \\
(-0.96)\end{array}$ \\
\hline $\mathrm{PROP}_{-}$Girl & $\begin{array}{c}-16.5^{*} \\
(-1.75)\end{array}$ & $\begin{array}{c}-19.42^{* *} \\
(-2.17)\end{array}$ & $\begin{array}{l}-8.22 \\
(-0.74)\end{array}$ & $\begin{array}{l}-17.52 \\
(-1.16)\end{array}$ & $\begin{array}{l}4.33 \\
(0.17)\end{array}$ \\
\hline TEACH_Math & $\begin{array}{c}1.85 * * * \\
(4.45)\end{array}$ & $\begin{array}{c}1.48^{* * *} \\
(4.18)\end{array}$ & $\begin{array}{c}0.88^{* *} \\
(2.03)\end{array}$ & $\begin{array}{l}1.4^{* *} \\
(2.35)\end{array}$ & $\begin{array}{c}0.8 \\
(1.26)\end{array}$ \\
\hline HOUSEWIFE & $\begin{array}{c}-16.4^{* * *} \\
(-3.88)\end{array}$ & $\begin{array}{c}-13.99^{* * *} \\
(-2.74)\end{array}$ & $\begin{array}{c}-14.05^{* * *} \\
(-2.89)\end{array}$ & $\begin{array}{c}-20.12^{* * *} \\
(-2.87)\end{array}$ & $\begin{array}{c}-25.1^{* *} \\
(-2.29)\end{array}$ \\
\hline Region dummies & YES & YES & YES & YES & YES \\
\hline Adjusted R2 & 0.30 & 0.22 & 0.13 & 0.10 & 0.09 \\
\hline $\mathrm{N}$ & 4185 & 3488 & 2325 & 1162 & 465 \\
\hline Number of Females & 2133 & 1727 & 1072 & 475 & 141 \\
\hline Number of Males & 2052 & 1761 & 1253 & 687 & 324 \\
\hline \multicolumn{6}{|c|}{$\begin{array}{l}\text { NOTE: The table reports our basic specification at different quantile of Math Literacy. The Math Literacy score is } \\
\text { derived from PISA 2012. REPEAT is a dummy variable equal to } 1 \text { if the student has repeated a grade. ESCS } \\
\text { is an index of student's economic, social and cultural status; LANG_Foreign indicates if the language spoken at } \\
\text { home is not the Italian language; PROP Girls indicates the Proportion of girls enrolled in the school; TEACH Math } \\
\text { is the percentage of Math Teachers in school; HOUSEWIFE is a dummy variable equal to } 1 \text { if the mother is } \\
\text { a housewife. The T - statistics computed with robust standard errors are in parenthesis below the coefficients. } \\
\text { *** p }<0.01,{ }^{* *} \mathrm{p}<0.05,{ }^{*} \mathrm{p}<0.1\end{array}$} \\
\hline
\end{tabular}


Table 6: Historical Determinants of Local Environment controlling for Math Literacy Scores.

\begin{tabular}{|c|c|c|c|c|c|}
\hline Dependent Variable & (1) & $(2)$ & $(3)$ & (4) & (5) \\
\hline \multicolumn{6}{|l|}{ Financial Literacy Score } \\
\hline FEMALE & $\begin{array}{c}-27.80^{* * *} \\
(-3.26)\end{array}$ & $\begin{array}{c}-4.75 \\
(-1.31)\end{array}$ & $\begin{array}{c}38.30^{* * *} \\
(2.45)\end{array}$ & $\begin{array}{c}-32.81^{* * *} \\
(-3.04)\end{array}$ & $\begin{array}{c}-83.39 * * * \\
(-2.91)\end{array}$ \\
\hline MATH_Score & $\begin{array}{c}0.48^{* * *} \\
(18.72)\end{array}$ & $\begin{array}{c}0.48^{* * *} \\
(18.54)\end{array}$ & $\begin{array}{c}0.48^{* * *} \\
(18.65)\end{array}$ & $\begin{array}{l}0.48^{* * *} \\
(18.653)\end{array}$ & $\begin{array}{c}0.48^{* * *} \\
(18.68)\end{array}$ \\
\hline COMM_Route & $\begin{array}{c}2.46^{* * *} \\
(5.98)\end{array}$ & & & & \\
\hline COMM_Route*FEMALE & $\begin{array}{c}0.47^{* * *} \\
(2.79)\end{array}$ & & & & \\
\hline NFS & & $\begin{array}{c}-0.43^{* * *} \\
(-4.52)\end{array}$ & & & \\
\hline NFS*FEMALE & & $\begin{array}{c}0.02 \\
(0.47)\end{array}$ & & & \\
\hline Stereotype Index & & & $\begin{array}{c}-5.38 * * * \\
(-5.79)\end{array}$ & & \\
\hline Stereotype Index*FEMALE & & & $\begin{array}{c}-1.31 * * * \\
(-2.79)\end{array}$ & & \\
\hline GEI & & & & $\begin{array}{c}3.78^{* * *} \\
(5.84)\end{array}$ & \\
\hline GEI*FEMALE & & & & $\begin{array}{c}0.83^{* * *} \\
(2.70)\end{array}$ & \\
\hline IGGI & & & & & $\begin{array}{c}9.33^{* * *} \\
(5.97)\end{array}$ \\
\hline IGGI*FEMALE & & & & & $\begin{array}{r}1.73^{* * *} \\
(2.75)\end{array}$ \\
\hline Region dummies & YES & YES & YES & YES & YES \\
\hline School dummies & YES & YES & YES & YES & YES \\
\hline Basic student dummies & YES & YES & YES & YES & YES \\
\hline Adjusted R2 & 0.08 & 0.08 & 0.08 & 0.08 & 0.08 \\
\hline $\mathrm{N}$ & 4651 & 4651 & 4651 & 4651 & 4651 \\
\hline
\end{tabular}

NOTE: The table shows the relevance of the historical determinants of the regional culture and their interaction with FEMALE on students' financial literacy score, when controlling also for math literacy. The Math Literacy score is derived from PISA 2012. COMM_Route is the \% of provinces which were on a medieval commercial route; NFS indicates the presence of a Nuclear Family Structure; Stereotype Index is an index of the peoples' belief in stereotypes; GEI is the Gender Equality Index; IGGI is the Italian Gender Gap Index based on four dimensions of which we take two: Political and Economic participation. The T-statistics computed with robust standard errors are reported in parenthesis below the coefficients. $* * * \mathrm{p}<0.01,{ }^{* *} \mathrm{p}<0.05,{ }^{*} \mathrm{p}<0.1$ 
Table 7: Endogenous Treatment Effect.

\begin{tabular}{|c|c|c|c|}
\hline Dependent Variable & Financial Literacy Score & Financial Literacy Score & Scientific Lyceum \\
\hline & Baseline & 2nd stage & 1st stage \\
\hline FEMALE & $\begin{array}{c}-19.01 \text { *** } \\
(-5.64)\end{array}$ & $\begin{array}{c}-17.30^{* *} \\
(-2.43)\end{array}$ & $\begin{array}{c}-0.14 \\
(-1.56)\end{array}$ \\
\hline AGE & $\begin{array}{c}-12.45^{* *} \\
(2.17)\end{array}$ & $\begin{array}{c}-16.68^{* *} \\
(2.53)\end{array}$ & $\begin{array}{l}0.037 \\
(0.32)\end{array}$ \\
\hline REPEAT & $\begin{array}{c}-40.78^{* * *} \\
(-8.46)\end{array}$ & $\begin{array}{c}-58.23^{* *} \\
(-2.25)\end{array}$ & $\begin{array}{c}-0.91 * * * \\
(-4,2)\end{array}$ \\
\hline ESCS & $\begin{array}{c}3.86^{* *} \\
(2.28)\end{array}$ & $\begin{array}{l}12.63 \\
(1.15)\end{array}$ & $\begin{array}{c}0.26^{* * *} \\
(6.08)\end{array}$ \\
\hline IMMIGRANT & $\begin{array}{c}-15.69^{* *} \\
(2.17)\end{array}$ & $\begin{array}{c}-18.80^{* *} \\
(-2.33)\end{array}$ & $\begin{array}{l}-0.16 \\
(-0.89)\end{array}$ \\
\hline LANG_Foreign & $\begin{array}{l}-9.86^{*} \\
(-1.69)\end{array}$ & $\begin{array}{c}-16.31 \\
(-1.5)\end{array}$ & $\begin{array}{c}-0.35 * * * \\
(-3.77)\end{array}$ \\
\hline PRIVATE SCHOOL & $\begin{array}{l}-16.65 \\
(-1.61)\end{array}$ & $\begin{array}{c}-23.16^{* *} \\
(-2.36)\end{array}$ & $\begin{array}{l}0.04 \\
(0.2)\end{array}$ \\
\hline CITY & $\begin{array}{l}1.76 \\
(0.37)\end{array}$ & $\begin{array}{c}5.81 \\
(0.93)\end{array}$ & $\begin{array}{c}0.10 \\
(0.62)\end{array}$ \\
\hline LARGE CITY & $\begin{array}{l}-0.97 \\
(-0.10)\end{array}$ & $\begin{array}{l}3.83 \\
(0.27)\end{array}$ & $\begin{array}{l}-0.20 \\
(-0.83)\end{array}$ \\
\hline PROP_Girls & $\begin{array}{l}-14.17 \\
(-1.64)\end{array}$ & $\begin{array}{c}7.72 \\
(0.75)\end{array}$ & $\begin{array}{l}-0.04 \\
(-0.17)\end{array}$ \\
\hline HOUSEWIFE & $\begin{array}{c}-18.65^{* * *} \\
(-4.41)\end{array}$ & $\begin{array}{c}19.97 * * * \\
(-3.73)\end{array}$ & $\begin{array}{c}-0.11 \\
(-1.11)\end{array}$ \\
\hline TECHNICAL SCHOOL & $\begin{array}{c}-48.83^{* * *} \\
(-8.53)\end{array}$ & & \\
\hline PROFESSIONAL SCHOOL & $\begin{array}{c}-93.84^{* * *} \\
(-11.74)\end{array}$ & & \\
\hline MIDDLE SCHOOL & $\begin{array}{c}-65.23^{* * *} \\
(-2.86)\end{array}$ & & \\
\hline VOCATIONAL SCHOOL & $\begin{array}{c}-102.94 * * * \\
(-9.69)\end{array}$ & & \\
\hline HUMANISTIC LYCEUM & $\begin{array}{c}-27.22^{* * *} \\
(-5.61)\end{array}$ & & \\
\hline SCIENTIFIC LYCEUM & & $\begin{array}{l}5.65 \\
(0.04)\end{array}$ & \\
\hline \% SCIENTIFIC LYCEUM & & & $\begin{array}{l}3.04^{* *} \\
(2.06)\end{array}$ \\
\hline Region dummies & YES & YES & YES \\
\hline & 4651 & 4651 & 4651 \\
\hline athrho & & $\begin{array}{c}0.36 \\
(0.28)\end{array}$ & \\
\hline $\operatorname{lnsigma}$ & & $\begin{array}{l}4.28^{* * *} \\
(33.25)\end{array}$ & \\
\hline \multicolumn{4}{|c|}{$\begin{array}{l}\text { NOTE: The table reports the results of the first and second stages of the Heckman estimation. Column (1) is our basic specification that we report for } \\
\text { comparison. Column (2) shows our second stage specification with financial literacy score as dependent variable. Column }(3) \text { reports the probability of stu- } \\
\text { dents choosing to enroll in a scientific lyceum. REPEAT is a dummy variable equal to } 1 \text { if the student has repeated a grade. ESCS is an index of student's } \\
\text { economic, social and cultural status; LANG F Foreign indicates if the language spoken at home is not the Italian language; PROP Girls indicates the Propor- } \\
\text { enon of }\end{array}$} \\
\hline
\end{tabular}


Table 8: Teaching Practice.

\begin{tabular}{|c|c|c|c|c|}
\hline Dependent Variable & (1) & $(2)$ & $(3)$ & $(4)$ \\
\hline \multicolumn{5}{|l|}{ Financial Literacy Score } \\
\hline FEMALE & $\begin{array}{r}-17.73^{* * *} \\
(-4.38)\end{array}$ & $\begin{array}{r}-25.08^{* * *} \\
(-5.86)\end{array}$ & $\begin{array}{r}-29.22^{* * *} \\
(-4.09)\end{array}$ & $\begin{array}{c}-15.86^{* * *} \\
(-3.93)\end{array}$ \\
\hline TEACH_think & & $\begin{array}{r}-5.89 \\
(-1.25)\end{array}$ & & \\
\hline TEACH_think*FEMALE & & $\begin{array}{r}16.22^{* * *} \\
(2.77)\end{array}$ & & \\
\hline TEACH_quest & & & $\begin{array}{r}-1.66 \\
(-0.29)\end{array}$ & \\
\hline TEACH_quest*FEMALE & & & $\begin{array}{r}16.68^{* *} \\
(2.30)\end{array}$ & \\
\hline COGNITIVE & & & & $\begin{array}{c}2.60 \\
(1.00)\end{array}$ \\
\hline COGNITIVE*FEMALE & & & & $\begin{array}{l}8.32^{* *} \\
(2.20)\end{array}$ \\
\hline Region dummies & YES & YES & YES & YES \\
\hline School dummies & YES & YES & YES & YES \\
\hline Basic student dummies & YES & YES & YES & YES \\
\hline Adjusted_R2 & 0.35 & 0.36 & 0.36 & 0.36 \\
\hline $\mathrm{N}--$ & 3018 & 3018 & 3018 & 3018 \\
\hline \multicolumn{5}{|c|}{$\begin{array}{l}\text { NOTE: The table reports the effect of teaching practices. Column (1) includes our basic controls. Col- } \\
\text { umn (2) includes TEACH think, which is a dummy variable equal to } 1 \text { if teacher asks to present rea- } \\
\text { soning during every lesson or most of the lessons. Column (3) includes TEACH_quest, which is a } \\
\text { dummy variable equal to } 1 \text { if teacher ask if students understood during every lesson or most of the } \\
\text { lessons. Column (4) includes COGNITIVE, which is an index for cognitive activation during math } \\
\text { lessons. The T-statistics computed with robust standard errors are in parenthesis below the coefficients. }\end{array}$} \\
\hline
\end{tabular}


Table 9: Discussion about Money with the Family.

\begin{tabular}{lcccc}
\hline Dependent Variable & $\mathbf{( 1 )}$ & $\mathbf{( 2 )}$ & $\mathbf{( 3 )}$ & $\mathbf{( 4 )}$ \\
\hline Financial Literacy Score & \multicolumn{5}{c}{ female $=0$} \\
\hline FEMALE & $-17.22^{* * *}$ & $-15.78^{* * *}$ & female $=1$ & $15.82^{* * *}$ \\
DISCUSS_Family & $(-3.66)$ & $(-2.35)$ & & $(2.87)$ \\
& & $15.88^{* * *}$ & $15.68^{* * *}$ & \\
DISCUSS_Family*FEMALE & & $(2.75)$ & $(2.84)$ & \\
& & -1.33 & & NO \\
Region dummies & $(-0.16)$ & & YES \\
School dummies & NO & NO & NO & YES \\
Basic student dummies & YES & YES & YES & 0.36 \\
Adjusted R2 & 0.35 & YES & YES & 1053 \\
N & 2109 & 2019 & 0.36 & 1056 \\
\hline
\end{tabular}

NOTE: The table considers the effect of discussing Money Matters with the family. Column (1) is our basic specification estimated on the sub-sample of respondents only. Column (2) includes the variable Discuss Family, which equal to 1 if students talk often about money with their family. In columns (3) and (4) the same specification is estimated for the sub-samples of females and males respectively. The T-statistics computed with robust standard errors are in parenthesis below the coefficients. $* * * \mathrm{p}<0.01,{ }^{* *} \mathrm{p}<0.05,{ }^{*} \mathrm{p}<0.1$ 
Table 10: Stereotype Index IV Estimates

\begin{tabular}{|c|c|c|c|c|}
\hline Dependent Variable & (1) & $(2)$ & (3) & (4) \\
\hline Financial Literacy Score & & first stage & & first stage \\
\hline FEMALE & $\begin{array}{l}25.11 \\
(0.53)\end{array}$ & & $\begin{array}{l}26.08 \\
(0.83)\end{array}$ & \\
\hline Stereotype Index & $\begin{array}{c}-4.44^{* * *} \\
(-4.04)\end{array}$ & & $\begin{array}{c}-1.73^{* *} \\
(-1.95)\end{array}$ & \\
\hline Stereotype Index*FEMALE & $\begin{array}{c}-1.39 \\
(-1.09)\end{array}$ & & $\begin{array}{c}0.91 \\
(0.91)\end{array}$ & \\
\hline MATH_Score & & & $\begin{array}{c}0.49^{* * *} \\
(18.46)\end{array}$ & \\
\hline Plough-pos environment & & $\begin{array}{l}0.12^{* *} \\
(23.12)\end{array}$ & & $\begin{array}{l}0.12^{* *} \\
(23.12)\end{array}$ \\
\hline Plough-neg environment & & $\begin{array}{c}-0.72^{* * * *} \\
(-35.26) \\
\end{array}$ & & $\begin{array}{c}-0.72 * * * \\
(-35.26) \\
\end{array}$ \\
\hline School Dummies & YES & YES & YES & YES \\
\hline Basic Student Dummies & YES & YES & YES & YES \\
\hline F-Stat (escl.ins.) & & 407 & & 418 \\
\hline Model p-value & 0.000 & 0.000 & 0 & 0 \\
\hline $\mathrm{N}$ & 4651 & 4651 & 4651 & 4651 \\
\hline
\end{tabular}


Table 11: Saving and Financial Literacy

\begin{tabular}{|c|c|c|c|c|}
\hline & (1) & $(2)$ & (3) & (4) \\
\hline Dependent Variable & PSAVE_A & PSAVE_A & PSAVE_B & PSAVE_B \\
\hline FEMALE & $\begin{array}{l}-0.25^{*} \\
(-1.15)\end{array}$ & female $=1$ & $\begin{array}{c}0.073 \\
(0.74)\end{array}$ & female $=1$ \\
\hline Financial Literacy Score & $\begin{array}{r}0.0002 \\
\quad(0.26)\end{array}$ & $\begin{array}{r}0.002^{* *} \\
(1.98)\end{array}$ & $\begin{array}{r}0.001^{* *} \\
(2.49)\end{array}$ & $\begin{array}{r}0.002^{* *} \\
(2.08)\end{array}$ \\
\hline AGE & $\begin{array}{c}-0.07 \\
(-0.31)\end{array}$ & $\begin{array}{l}-0.18 \\
(-0.66)\end{array}$ & $\begin{array}{r}-0.01 \\
(-0.04)\end{array}$ & $\begin{array}{r}-0.02 \\
(-0.10)\end{array}$ \\
\hline REPEAT & $\begin{array}{c}-0.59 * * * \\
(-3.60)\end{array}$ & $\begin{array}{l}-0.27 \\
(-0.98)\end{array}$ & $\begin{array}{c}0.044 \\
(0.27)\end{array}$ & $\begin{array}{r}0.27 \\
(1.09)\end{array}$ \\
\hline ESCS & $\begin{array}{l}-0.04 \\
(-0.65)\end{array}$ & $\begin{array}{l}-0.05 \\
(0.63)\end{array}$ & $\begin{array}{l}-0.002 \\
(-0.03)\end{array}$ & $\begin{array}{r}0.09 \\
(1.19)\end{array}$ \\
\hline IMMIGRANT & $\begin{array}{c}-0.12 \\
(-0.52)\end{array}$ & $\begin{array}{l}-0.13 \\
(-0.48)\end{array}$ & $\begin{array}{r}0.18 \\
(0.85)\end{array}$ & $\begin{array}{r}0.18 \\
(0.56)\end{array}$ \\
\hline CITY & $\begin{array}{c}-0.43^{* *} \\
(-2.29)\end{array}$ & $\begin{array}{c}-0.46^{* * *} \\
(-2.62)\end{array}$ & $\begin{array}{r}0.03 \\
(0.30)\end{array}$ & $\begin{array}{r}0.45^{* * *} \\
(2.59)\end{array}$ \\
\hline LARGE_CITY & $\begin{array}{l}-0.38 \\
(-0.65)\end{array}$ & $\begin{array}{l}-0.71^{*} \\
(-1.93)\end{array}$ & $\begin{array}{c}0.48^{*} \\
(1.90)\end{array}$ & $\begin{array}{r}1.04^{* * *} \\
(2.69)\end{array}$ \\
\hline HOUSEWIFE & $\begin{array}{l}-0.15 \\
(-1.21)\end{array}$ & $\begin{array}{l}-2.29 \\
(-1.60)\end{array}$ & $\begin{array}{r}-0.10 \\
(-0.81)\end{array}$ & $\begin{array}{r}-0.13 \\
(-0.84)\end{array}$ \\
\hline Region dummies & YES & YES & YES & YES \\
\hline $\mathrm{N}$ & 1803 & 963 & 2029 & 1016 \\
\hline
\end{tabular}

